\title{
17. PETROGRAPHY AND GEOCHEMISTRY OF ORGANIC MATTER IN TRIASSIC AND CRETACEOUS DEEP-SEA SEDIMENTS FROM THE WOMBAT AND EXMOUTH PLATEAUS AND NEARBY ABYSSAL PLAINS OFF NORTHWEST AUSTRALIA 1
}

\author{
Jürgen Rullkötter, ${ }^{2}$ Ralf Littke, ${ }^{2}$ Matthias Radke, ${ }^{2}$ Ulrich Disko, ${ }^{2}$ Brian Horsfield, ${ }^{2}$ and Jürgen Thurow ${ }^{3}$
}

\begin{abstract}
Triassic (Carnian-Rhaetian) continental margin sediments from the Wombat Plateau off northwest Australia (Sites 759, 760, 761, and 764) contain mainly detrital organic matter of terrestrial higher plant origin. Although deposited in a nearshore deltaic environment, little liptinitic material was preserved. The dominant vitrinites and inertinites are hydrogen-lean, and the small quantities of extractable bitumen contain $n$-alkanes and bacterial hopanoid hydrocarbons as the most dominant single gas-chromatography-amenable compounds.

Lower Cretaceous sediments on the central Exmouth Plateau (Sites 762 and 763) farther south in general have an organic matter composition similar to that in the Wombat Plateau sediments with the exception of a smaller particle size of vitrinites and inertinites, indicating more distal transport and probably deposition in deeper water. Nevertheless, organic matter preservation is slightly better than in the Triassic sediments. Long-chain fatty acids, as well as aliphatic ketones and alcohols, are common constituents in the Lower Cretaceous sediments in addition to $n$-alkanes and hopanoid hydrocarbons.

Thin, black shale layers at the Cenomanian/Turonian boundary, although present at several sites (Sites 762 and 763 on the Exmouth Plateau, Site 765 in the Argo Abyssal Plain, and Site 766 on the continental margin of the Gascoyne Abyssal Plain), are particularly enriched in organic matter only at Site 763 (up to 26\%). These organic-matter-rich layers contain mainly bituminite of probable fecal-pellet origin. Considering the high organic carbon content, the moderate hydrogen indices of 350-450 milligrams of hydrocarbon-type material per gram of $\mathrm{C}_{\text {org }}$, the maceral composition, and the low sedimentation rates in the middle Cretaceous, we suggest that these black shales were accumulated in an area of oxygen-depleted bottom-water mass (oceanwide reduced circulation?) underlying an oxygen-rich water column (in which most of the primary biomass other than fecal pellets is destroyed) and a zone of relatively high bioproductivity. Differences in organic matter accumulation at the Cenomanian/ Turonian boundary at different sites off northwest Australia are ascribed to regional variations in primary bioproductivity.
\end{abstract}

\section{INTRODUCTION}

During Ocean Drilling Program (ODP) Legs 122 and 123 a series of holes was drilled to study the Mesozoic sedimentary history on the continental margin off northwest Australia (von Rad et al., 1989). For this purpose, two transects were drilled on the Wombat Plateau (Sites 759-761 and 764) and on the Exmouth Plateau down to the margin of the Gascoyne Abyssal Plain (Sites 762-763 and 766). These holes were complemented by drilling at Site 765 in the Argo Abyssal Plain (Fig. 1). Triassic early rift sediments, unconformably overlain by Cretaceous post-rift sediments, were recovered, whereas Jurassic sediments witnessing a major late-rift block faulting event were missing (Shipboard Scientific Party, 1990b). This situation is roughly similar to that on the Galicia passive continental margin off Portugal where drilling during Leg 103 recovered only pre- and post-rift deposits (Boillot, Winterer, Meyer, et al., 1987).

The Northwest Shelf of Australia, comprising four major sedimentary basins (Carnarvon, offshore Canning, Browse, and Bonaparte, from south to north, respectively), is one of this continent's important petroleum provinces (Purcell and Purcell, 1988a) with estimated undiscovered reserves of 1500 million barrels of oil and 20 trillion cubic feet of gas (Purcell and Purcell,

\footnotetext{
1 von Rad, U., Haq, B. U., et al., 1992. Proc. ODP, Sci. Results, 122: College Station, TX (Ocean Drilling Program).

2 Institut für Erdöl und Organische Geochemie, Forschungszentrum Jülich GmbH (KFA), Postfach 19 13, D-5170 Jülich 1, Federal Republic of Germany.

${ }^{3}$ Institut für Geologie, Ruhruniversität Bochum, D-4630 Bochum, Federal Republic of Germany.
}

1988b). In contrast, exploratory drilling on the Exmouth Plateau, which forms a distal part of the Northwest Shelf of Australia, discovered only noncommercial dry gas accumulations, including the Scarborough Gas Field, and many of the commercial wells were abandoned dry (Barber, 1988). A minor petroleum generation potential was ascribed to some of the sediments on the Exmouth Plateau (e.g., Exon and Willcox, 1978, 1980; Cook et al., 1985; Barber, 1988), although lack of sufficiently deep burial apparently prevented its realization (Barber, 1988).

It was our objective to characterize the distribution and composition of organic matter in deep-sea sediments farther offshore but stratigraphically equivalent to those studied earlier. Special emphasis was placed on the possible occurrence of Cretaceous black shales, particularly those at the Cenomanian/ Turonian boundary which are well documented in many other areas of the world's oceans (e.g., Herbin et al. 1986; Arthur et al., 1987). Furthermore, we were interested in the effects of the supply of terrigenous organic matter on the bulk preservation of organic matter in continental margin sediments. Our organic petrographic and molecular organic geochemical analyses of deep-sea sediments from the Exmouth Plateau are complementary to those of Meyers and Snowdon (this volume) and Snowdon and Meyers (this volume).

\section{SAMPLES AND EXPERIMENTAL METHODS}

\section{Samples}

A total of 57 samples was collected for this study aboard the JOIDES Resolution at eight sites during Legs 122 and 123 (Fig. 1) with a bias toward sediments that gave the impression 


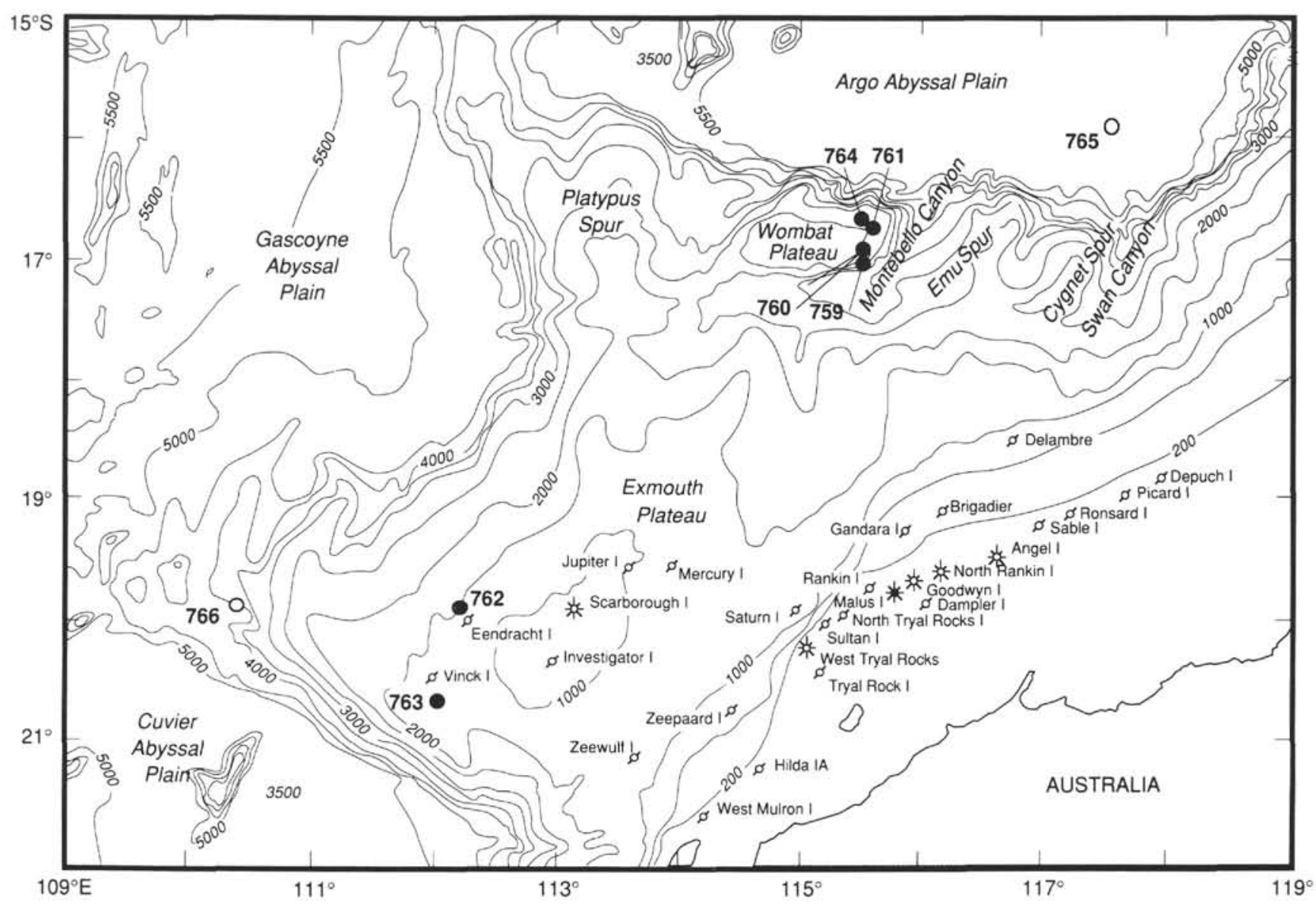

Figure 1. Location of drilling sites on the northwest Australian continental margin during Legs 122 (solid circles) and 123 (open circles) (from Shipboard Scientific Party, 1990b). Also shown are locations of commercial wells (standard industry symbols). Locations of Sites 762 and 763 , although shown slightly offset, actually are identical to those of commercial wells Eendracht I and Vinck I, respectively.

of having high organic carbon contents (black or dark color). The samples are listed in Table 1 together with depth and stratigraphic age information. The lithology of selected samples studied in greater detail (microscopy and molecular bitumen analysis) is described in Table 2. Aside from a few samples of Tertiary age, all others are of Triassic or Cretaceous age. Six samples are from the Argo Abyssal Plain (Site 765), 22 from the Exmouth Plateau, and 19 from the Wombat Plateau.

\section{Experimental Methods}

Sediment samples were received frozen and after thawing were dried at $40^{\circ} \mathrm{C}$. Whole-rock aliquots were set aside for kerogen microscopy and the remainder was ground in a disc mill. Total carbon and organic carbon $\left(\mathrm{C}_{\text {org }}\right)$ were determined by combustion in a LECO IR-112 carbon analyzer. The latter measurement was performed after treatment of the samples with hydrochloric acid to destroy carbonates. Inorganic carbon contents were calculated by difference and converted to percent calcium carbonate $\left(\mathrm{CaCO}_{3}\right)$ on the assumption that this was the sole carbonate species. Rock-Eval pyrolysis was performed using a Rock-Eval II instrument (Girdel). Hydrogen index (HI) and oxygen index (OI) values in Table 1 are determined from flame ionization (FID) and thermal conductivity detector responses and expressed as milligram hydrocarbon-type material per gram $\mathrm{C}_{\text {org }}$ and $\mathrm{CO}_{2}$ per gram $\mathrm{C}_{\text {org }}$, respectively.

For microscopic studies, whole-rock samples were embedded in a resin in orientation perpendicular to bedding, then ground flat and polished. Maceral abundances (Table 3) were determined using point counting, first in reflected white light, then in fluorescence mode on a Zeiss Photomicroscope III with a step-width of $0.33 \mathrm{~mm}$ on parallel lines perpendicular to bedding. Six hundred points per sample were evaluated in this way. A detailed description of macerals has been given by Stach et al. (1982). Within the liptinite maceral group, bituminites are all non- or weakly-fluorescing liptinite particles with variable shapes which, in contrast to the shapes of some liptinite particles, cannot be correlated with the morphologies of known biological precursor organisms. In the case of the Leg 122/123 samples, bituminites were easily recognized because they were larger than other organic particles. Lengths of terrigenous particles were determined in incident white light by measuring the largest axis of each particle in a selected area. Vitrinite reflectance (random reflectance, or $\mathrm{R}_{\mathrm{r}}$ ) was measured in oil immersion at $546 \mathrm{~nm}$.

Ground sediments were extracted with dichloromethane (containing $1 \%$ methanol) using a modified flow-blending technique (Radke et al., 1978). Total extracts were not further separated for this study but treated with diazomethane and N,O-bis-(trimethylsilyl)-trifluoroacetamide (BSTFA) to transform free acids and alcohols into their methyl ester and trimethylsilyl (TMS) ether derivatives, respectively, and analyzed directly by gas chromatography (GC) and combined gas chromatography-mass spectrometry (GC-MS).

For GC analysis, a Hewlett Packard HP 5730A instrument equipped with dual FID and flame photometric (FPD) detec- 
tors was used. Samples were injected onto a $50-\mathrm{m} \times 0.2-\mathrm{mm}$ inner diameter fused silica column coated with Ultra-2 (HP) at a film thickness of $0.33 \mu \mathrm{m}$. The temperature program was as follows: $120^{\circ} \mathrm{C}(4 \mathrm{~min})-3^{\circ} \mathrm{C} / \mathrm{min}-310^{\circ} \mathrm{C}$.

A Finnigan 5100 quadrupole GC-MS instrument was used for molecular analysis of total extracts. Full mass spectra were acquired in the mass-to-charge $(\mathrm{m} / \mathrm{z})$ range of $42-650$ at a cycle time of $1 \mathrm{~s} / \mathrm{scan}$. The GC oven was equipped with the same type of column used for GC analysis. The temperature program started at $110^{\circ} \mathrm{C}$ but otherwise was identical to that for GC analysis. Molecular constituents were identified based on mass spectral interpretation, relative retention times, and comparison with published spectra.

\section{RESULTS AND DISCUSSION}

\section{Wombat Plateau (Triassic)}

Apart from three Tertiary sediments with negligible organic carbon contents $(0.04 \%$; Table 1$)$ all Wombat Plateau samples are of Carnian to Rhaetian age. Despite their uniformly black or dark green to black color the organic carbon contents in these Triassic sediments (predominantly claystones with the exception of the two Rhaetian sediments from Hole 761C) vary from about $0.5 \%$ to almost $3 \%$ (Table 1). Maceral analysis from kerogen microscopy showed that all Triassic sediments are extremely poor in marine organic particles (alginite, liptodetrinite, and bituminite), but contain significant amounts of terrigenous macerals (Table 3 ). Extremely low hydrogen indexes (20-150 mg hydrocarbons/g $\mathrm{C}_{\text {org }}$ ) from Rock-Eval pyrolysis are consistent with the presence of terrigenous organic matter in all Triassic samples with often poor preservation (oxidation during transport, inertinite formation).

Among the terrigenous macerals, inertinite does not predominate as observed in typical open-marine sediments (e.g., Littke et al., in press), but vitrinite and inertinite are of approximately equal abundance in most cases. The highest vitrinite/inertinite ratios $(2-3)$ were observed in the oldest sediments of early to middle Carnian age recovered at Site 759. This ratio is near unity in the Norian samples. The lower Norian and Carnian samples contain up to $1 \%$ sporinite and cutinite (Table 3).

Like the vitrinite/inertinite ratio (as a measure of oxidation during transport) the grain size of terrigenous organic particles can be used as an indicator of the proximity of source(s) of woody material (Cornford, 1979; Cornford et al., 1980). The size of the terrigenous particles in the Triassic sediments from the Wombat Plateau varies considerably. While small particles of less than $30 \mu \mathrm{m}$ in length predominate in number, vitrinites and inertinites larger than $30 \mu \mathrm{m}$ form the bulk of the organic matter in some of the Triassic sediments. The upper Carnian to lower Norian sediments drilled at Site 760 between 293 and 430 meters below seafloor (mbsf) contain the largest organic particles. Smaller grain sizes are characteristic of the Carnian sediments at Site 759, the upper Norian deposits at Site 760 between 112 and 236 mbsf, and the Rhaetian sediment at Site 761 (Fig. 2A-C).

The reason for the variation in organic particle size may be either a more proximal source of the terrigenous matter or a more energetic hydraulic regime during the late Carnian to early Norian. We favor the second explanation because the general sedimentological characteristics of the different lithologic units do not suggest a shallower water depth in the late Carnian to early Norian; furthermore, the generally coarse grain size of the terrigenous particles is consistent with a persistently shallow water level during the entire Carnian and Norian, probably in a nearshore deltaic setting (see Haq, von Rad, O'Connell, et al., 1990).
In the Triassic sediments (as well as in the Cretaceous sediments from the Exmouth Plateau discussed hereafter) almost all of the organic matter under incident light microscopy appears to be visible as organic particles larger than the resolution of the light microscope (about $1 \mu \mathrm{m}$ ). This observation is supported by a correlation of the percentage of macerals to the organic carbon content in Figure 3 . The calculated regression line shows an approximately $2: 1$ relationship of the volume percentages of macerals to the weight percentages of organic carbon as expected in the case of complete recognition of organic matter under the microscope (Smyth, 1983; Scheidt and Littke, 1989). Some deviation from this line is common due to variations in mineral composition (density) of the sediments. Thus, quoting a correlation coefficient is not meaningful in this case. Apparently, in Leg 122 sediments there is almost no submicroscopic organic matter typical of sediments containing abundant microalgae or other highly liptinitic (aquatic) organic matter reworked by sedimentary bacteria, as observed, for example, in coastal upwelling sediments off Peru (ten Haven et al., 1990). There, the macerals/organic carbon relationship has an extremely steep slope (i.e., few recognized macerals at high organic carbon values).

One of the samples studied (Sample 122-759B-39R-3, 57-62 $\mathrm{cm}$; Carnian) contains abundant vitrinite particles with reflectance values between $0.4 \%$ and $0.6 \%$ (Fig. $4 \mathrm{~A}$ ), but it is not clear that these particles represent reworked debris from older sedimentary units containing more mature organic matter. Typical vitrinite reflectance values in the Triassic sediments vary between $0.3 \%$ and $0.4 \%$ (Fig. $4 \mathrm{~B},-\mathrm{C}$ ). Thus, the organic matter in the Triassic Wombat Plateau sediments is immature with respect to hydrocarbon generation, and the discussion of variations in organic carbon content, hydrogen indexes, and maceral composition is related to facies aspects only and not to changes in thermal maturity.

Total extract yields for the Triassic sediments are very low ( $<5 \mathrm{mg} / \mathrm{g} \mathrm{C}_{\mathrm{org}}$ on average with only the Rhaetian sample just exceeding $7 \mathrm{mg} / \mathrm{g} \mathrm{C}_{\text {org }}$ ). This result is in agreement with the overall organic matter type and level of preservation as determined by kerogen microscopy and Rock-Eval pyrolysis. Typical extract yields of deep-sea sediments containing mainly marine organic matter are higher by a factor of two or more (e.g., Rullkötter et al., 1981; ten Haven et al., 1990; see also the section on Exmouth Plateau samples, this chapter). The low extract yields of the Triassic sediments from the Wombat Plateau, in combination with the small size of the samples, caused disturbance of the molecular bitumen analysis by a variety of plasticizer contaminants (e.g., phthalate esters and higher esters of alkanedioic acids) probably acquired during sampling and sample transport in plastic containers. All total bitumen gas chromatograms are dominated by these compounds as shown for a Norian and a Carnian sample for which the yield of indigenous components was highest (Fig. 5A, -B; Table 4). Normal-alkanes are the most abundant group of naturally occurring single compounds in all cases. An origin from higher plant waxes is obvious from the dominance of the odd carbon number homologs in the higher molecular weight range with maxima at $n-C_{27}$ (see Eglinton and Hamilton, 1963). Oxygen-bearing aliphatic compounds (acids, alcohols) are minor constituents only. Many of these may have been fully destroyed by oxidation during transport and in the oxygenated uppermost sediment layer after depo-sition. The next most abundant naturally occurring compound class in the Wombat Plateau sediments is hopanoid hydrocarbons of microbial origin (Ourisson et al., 1979). A distribution of hopanes and hopenes typical of Triassic sediments from the Wombat 
Table 1. Organic carbon, carbonate, and Rock-Eval pyrolysis data for sediments of the Wombat and Exmouth plateaus.

\begin{tabular}{|c|c|c|c|c|c|c|c|}
\hline $\begin{array}{l}\text { Core, section, } \\
\text { interval }(\mathrm{cm})\end{array}$ & $\begin{array}{l}\text { Depth } \\
\text { (mbsf) }\end{array}$ & Age & $\begin{array}{c}\mathrm{CaCO}_{3} \\
(\%)\end{array}$ & $\begin{array}{l}\mathrm{C}_{\text {org }} \\
(\%)\end{array}$ & $\mathrm{HI}^{\mathrm{a}}$ & $\mathrm{OI}^{\mathrm{b}}$ & $\begin{array}{l}\mathrm{T}_{\max } \\
\left({ }^{\circ} \mathrm{C}\right)\end{array}$ \\
\hline \multicolumn{8}{|l|}{ Leg 122} \\
\hline \multicolumn{8}{|l|}{$122-759 \mathrm{~B}-$} \\
\hline $11 \mathrm{R}-2,66-70$ & 90.14 & Carnian & 42.0 & 2.39 & 149 & 42 & 412 \\
\hline $19 \mathrm{R}-2,28-38$ & 165.78 & Carnian & 1.3 & 2.42 & 44 & 63 & 430 \\
\hline $21 \mathrm{R}-1,83-90$ & 183.83 & Carnian & 0.5 & 1.41 & 76 & 46 & 430 \\
\hline $35 \mathrm{R}-3,20-24$ & 277.70 & Carnian & 3.4 & 1.17 & 39 & 173 & 430 \\
\hline $39 \mathrm{R}-3,57-62$ & 302.07 & Carnian & 6.2 & 1.17 & 34 & 362 & 430 \\
\hline \multicolumn{8}{|l|}{$122-760 \mathrm{~A}-$} \\
\hline $7 \mathrm{H}-3,71-77$ & 58.91 & upper Oligocene & 85.5 & 0.04 & n.d. & n.d. & n.d. \\
\hline $13 \mathrm{X}-1,41-49$ & 112.61 & Norian & 0.4 & 1.36 & 38 & 67 & 458 \\
\hline $25 X-5,140-147$ & 210.30 & Norian & 2.4 & 0.35 & 111 & 163 & 446 \\
\hline $30 \mathrm{X}-3,121-128$ & 236.61 & Norian & 2.7 & 2.96 & 37 & 160 & 429 \\
\hline $34 X-1,53-56$ & 259.93 & Norian & 0.0 & 1.59 & 35 & 50 & 426 \\
\hline $37 X-3,59-64$ & 282.49 & Norian & 4.5 & 1.01 & 22 & 113 & 424 \\
\hline \multicolumn{8}{|l|}{$122-760 \mathrm{~B}-$} \\
\hline $7 \mathrm{R}-1,95-99$ & 293.45 & Norian & 0.6 & 2.64 & 36 & 52 & 427 \\
\hline $8 \mathrm{R}-\mathrm{CC}, 16-21$ & 306.47 & Norian & 2.4 & 2.28 & 29 & 73 & 425 \\
\hline $16 \mathrm{R}-4,108-115$ & 383.59 & Norian & 0.3 & 1.23 & 37 & 64 & 425 \\
\hline $21 \mathrm{R}-4,27-36$ & 430.27 & Carnian & 0.2 & 1.22 & 33 & 32 & 426 \\
\hline \multicolumn{8}{|l|}{$122-761 \mathrm{~B}-$} \\
\hline $9 \mathrm{H}-3,83-90$ & 74.53 & middle Eocene & 91.3 & 0.04 & n.d. & n.d. & n.d. \\
\hline $14 X-4,80-86$ & 107.00 & middle Eocene & 88.0 & 0.04 & n.d. & n.d. & n.d. \\
\hline \multicolumn{8}{|l|}{$122-761 C$} \\
\hline 26R-3, 133-140 & 370.03 & Rhaetian & 25.2 & 0.54 & 22 & 391 & 420 \\
\hline $31 \mathrm{R}-2,148-150$ & 411.18 & Rhaetian & 36.4 & 0.93 & 14 & 297 & 420 \\
\hline \multicolumn{8}{|l|}{$122-762 \mathrm{~B}-$} \\
\hline $13 \mathrm{H}-2,83-90$ & 111.22 & upper Miocene & 88.5 & 0.08 & n.d. & n.d. & n.d. \\
\hline \multicolumn{8}{|l|}{$122-762 C$} \\
\hline $10 \times-3,55-60$ & 249.55 & middle Eocene & 42.1 & 0.04 & n.d. & n.d. & n.d. \\
\hline $31 X-2,66-73$ & 442.66 & upper Paleocene & 85.3 & 0.06 & n.d. & n.d. & n.d. \\
\hline $46 \mathrm{X}-1,103-110$ & 584.03 & upper Maestrichtian & 94.6 & 0.04 & n.d. & n.d. & n.d. \\
\hline $54 X-7,24-31$ & 668.24 & upper Campanian & 74.7 & 0.06 & n.d. & n.d. & n.d. \\
\hline $77 \times-1,108-115$ & 820.58 & upper Albian & 55.6 & 0.05 & n.d. & n.d. & n.d. \\
\hline $79 \times-1,139-142$ & 839.89 & lower Aptian & 4.9 & 0.69 & 36 & 70 & 417 \\
\hline $79 \times-2,139-142$ & 841.39 & lower Aptian & 1.9 & 0.71 & 37 & 48 & 417 \\
\hline $81 X-3,74-81$ & 852.24 & lower Valanginian & 1.3 & 1.49 & 50 & 50 & 417 \\
\hline $82 X-2,130-137$ & 856.30 & upper Berriasian & 0.3 & 1.25 & 82 & 44 & 416 \\
\hline $89 X-2,47-54$ & 912.97 & Berriasian & 1.4 & 0.87 & 68 & 69 & 421 \\
\hline \multicolumn{8}{|l|}{$122-763 \mathrm{~B}-$} \\
\hline $24 \mathrm{X}-\mathrm{CC}, 25-32$ & 408.68 & Cenomanian & 34.0 & 0.23 & n.d. & n.d. & n.d. \\
\hline $35 \mathrm{X}-3,53-60$ & 507.03 & lower-middle Albian & 35.2 & 0.28 & n.d. & n.d. & n.d. \\
\hline $37 \mathrm{X}-5,80-89$ & 528.58 & lower Albian & 56.1 & 0.06 & n.d. & n.d. & n.d. \\
\hline $44 X-3,12-16$ & 592.12 & lower Aptian & 9.6 & 0.46 & 43 & 170 & 416 \\
\hline $46 X-6,77-82$ & 615.56 & lower Aptian & 1.0 & 1.12 & 57 & 42 & 417 \\
\hline \multicolumn{8}{|l|}{$122-763 C$} \\
\hline 2R-1, 19-21 & 385.20 & Cenomanian-Turonian & 0.6 & 2.45 & 100 & 53 & 414 \\
\hline $2 \mathrm{R}-1,24-26$ & 385.25 & Cenomanian-Turonian & 0.3 & 8.99 & 354 & 38 & 407 \\
\hline $2 \mathrm{R}-1,28-30$ & 385.28 & Cenomanian-Turonian & 2.5 & 25.9 & 458 & 37 & 401 \\
\hline $2 \mathrm{R}-1,44-46$ & 385.45 & Cenomanian-Turonian & 0.0 & 0.25 & 92 & 88 & 444 \\
\hline $2 \mathrm{R}-1,61-63$ & 385.62 & Cenomanian-Turonian & 0.0 & 2.89 & 126 & 40 & 419 \\
\hline $2 \mathrm{R}-1,71-73$ & 385.72 & Cenomanian-Turonian & 0.0 & 0.30 & 47 & 60 & n.d. \\
\hline $2 \mathrm{R}-1,88-90$ & 385.89 & Cenomanian-Turonian & 37.9 & 0.25 & 12 & 368 & n.d. \\
\hline $8 R-3,16-23$ & 673.76 & upper Berriasian & 3.4 & 1.87 & 173 & 76 & 429 \\
\hline $10 \mathrm{R}-4,4-11$ & 689.64 & middle-upper Berriasian & 5.1 & 1.08 & 125 & 69 & 428 \\
\hline $22 \mathrm{R}-3,63-70$ & 802.73 & middle-upper Berriasian & 4.7 & 0.92 & 117 & 61 & 425 \\
\hline $29 \mathrm{R}-6,34-42$ & 873.44 & middle-upper Berriasian & 4.8 & 1.39 & 162 & 77 & 430 \\
\hline \multicolumn{8}{|l|}{$122-764 \mathrm{~B}-$} \\
\hline $31 \mathrm{R}-5,104-110$ & 286.54 & Rhaetian & 57.7 & 0.48 & 19 & 269 & 420 \\
\hline \multicolumn{8}{|l|}{ Leg 123} \\
\hline \multicolumn{8}{|l|}{$123-765 \mathrm{C}$ - } \\
\hline $24 \mathrm{R}-2,55-57$ & 571.36 & lower Campanian & 0.3 & 0.08 & n.d. & n.d. & n.d. \\
\hline $26 \mathrm{R}-1,52-56$ & 588.84 & Cenomanian-Turonian & 0.3 & 0.12 & n.d. & n.d. & n.d. \\
\hline
\end{tabular}


Table 1 (continued).

\begin{tabular}{|c|c|c|c|c|c|c|c|}
\hline $\begin{array}{l}\text { Core, section, } \\
\text { interval }(\mathrm{cm})\end{array}$ & $\begin{array}{l}\text { Depth } \\
\text { (mbsf) }\end{array}$ & Age & $\begin{array}{c}\mathrm{CaCO}_{3} \\
(\%)\end{array}$ & $\begin{array}{l}\mathrm{C}_{\text {org }} \\
(\%)\end{array}$ & $\mathrm{HI}^{\mathrm{a}}$ & $\mathrm{OI}^{\mathrm{b}}$ & $\begin{array}{l}\mathrm{T}_{\max } \\
\left({ }^{\circ} \mathrm{C}\right)\end{array}$ \\
\hline $26 \mathrm{R}-1,78-82$ & 589.10 & Cenomanian-Turonian & 0.2 & 0.05 & n.d. & n.d. & n.d. \\
\hline 26R-1, 107-109 & 589.38 & Cenomanian-Turonian & 0.3 & 0.06 & n.d. & n.d. & n.d. \\
\hline $26 \mathrm{R}-1,122-124$ & 589.53 & Cenomanian-Turonian & 0.5 & 0.10 & n.d. & n.d. & n.d. \\
\hline $45 \mathrm{R}-4,100-104$ & 773.72 & lower Aptian & 1.8 & 4.35 & 59 & 75 & 409 \\
\hline \multicolumn{8}{|l|}{$123-766 \mathrm{~A}-$} \\
\hline $15 \mathrm{R}-2,102-106$ & 134.74 & Cenomanian-Turonian & 0.0 & 0.08 & n.d. & n.d. & n.d. \\
\hline $15 \mathrm{R}-2,111-115$ & 134.83 & Cenomanian-Turonian & 0.3 & 0.08 & n.d. & n.d. & n.d. \\
\hline $15 R-2,139-143$ & 135.11 & Cenomanian-Turonian & 0.0 & 0.11 & n.d. & n.d. & n.d. \\
\hline $15 \mathrm{R}-3,29-31$ & 135.50 & Cenomanian & 0.2 & 0.66 & n.d. & n.d. & n.d. \\
\hline
\end{tabular}

Note: n.d. = not determined.

${ }^{\mathrm{a}} \mathrm{HI}=$ hydrogen index ( $\mathrm{mg}$ hydrocarbons $/ \mathrm{g} \mathrm{C}_{\mathrm{org}}$ ).

${ }^{\mathrm{b}} \mathrm{OI}=$ oxygen index $\left(\mathrm{mg} \mathrm{CO} 2 / \mathrm{g} \mathrm{C}_{\text {org }}\right)$.

Plateau is shown in Figure 6. The $17 \beta(\mathrm{H}), 21 \beta(\mathrm{H})$-hopanes dominate and indicate that the sediments have been exposed only to low thermal stress. The predominance of neohop13(18)-enes over hop-17(21)-enes probably reflects the oxic depositional environment because the former compounds appear to be the more stable isomers toward oxidation (see Brassell et al., 1980). The occurrence of small amounts of $\mathrm{C}_{29}$ sterols, likely to be of terrigenous origin, in Sample 122-760B-8R-CC, 16-21 cm (Fig. 5A), is exceptional among the Wombat Plateau sediments. Most of the labile steroids will have been destroyed by oxidation.

The occurrence of retene in the Carnian samples testifies further to the higher plant origin of the organic matter (gymnosperm diterpenoids) and to oxidative transformation (aromatization) of the biogenic precursor material during transport from the continent and deposition. Benzofluoranthene was the next most abundant single aromatic hydrocarbon identified. A complex mixture of highly aromatic compounds (including benzopyrenes and perylene) is present in both the Carnian and Norian samples (Fig. 5A, -B). Sulfurbearing aromatic compounds were not detected in the total extracts.

\section{Exmouth Plateau (Cretaceous)}

Light-colored Tertiary and Upper Cretaceous sediments from the Exmouth Plateau are extremely lean in organic carbon (Table 1) and will not be discussed further. Despite their darker (green) color, the same applies to Albian sediments and to Cenomanian/Turonian sediments at Site 766 (Table 1). Lower Cretaceous sediments on the Exmouth Plateau contain between $0.5 \%$ and $2 \%$ organic carbon; exceptionally high values were recorded in the black shales at the Cenomanian/Turonian boundary at Site 763 (Table 1).

Hydrogen indexes of the Lower Cretaceous sediments are low and typical of sediments containing mainly refractory oxidized terrigenous organic matter. They are similar to those of the Triassic sediments on the Wombat Plateau. Only the Berriasian samples from Hole $763 \mathrm{C}$ exhibit hydrogen index values exceeding $100 \mathrm{mg}$ hydrocarbons per $\mathrm{g} \mathrm{C}_{\text {org }}$. According to Rock-Eval pyrolysis results, the organic-carbon-rich Cenomanian/Turonian boundary black shale (Samples 122-763C$2 \mathrm{R}-1,24-26 \mathrm{~cm}$, and $122-763 \mathrm{C}-2 \mathrm{R}-1,28-30 \mathrm{~cm}$ ) is likely to contain a mixture of marine organic matter and terrigenous material (HI values of 350 and $450 \mathrm{mg}$ hydrocarbons/g $\mathrm{C}_{\mathrm{org}}$ ). In view of the extremely high organic carbon content $(26 \%)$, the hydrogen index of Sample 122-763C-2R-1, 28-30 cm (458 mg hydrocarbons $/ \mathrm{g} \mathrm{C}_{\text {org }}$ ) is still remarkably low but similar to the $\mathrm{HI}$ values of organic-matter-rich black shales of the same age in the Atlantic Ocean (e.g., at DSDP Site 603 off Cape
Hatteras). Previously, this has been ascribed to a significant microbial reworking of marine organic matter or the preferential accumulation of zooplankton fecal pellets (Rullkötter et al., 1987).

Kerogen microscopy revealed a decreased inflow of terrigenous particles during the Cretaceous compared to the Triassic sequence on the Wombat Plateau (Table 3 ). This implies roughly equal or even slightly lower sedimentation rates in the Cretaceous section (Triassic: $1.3-4 \mathrm{~cm} / \mathrm{k} . \mathrm{y}$; Cretaceous: 1-2 cm/k.y.; Haq, von Rad, O'Connell, et al., 1990). On the other hand, there is no significant increase in the percentages of marine organic particles except for the thin Cenomanian/Turonian black shales in Section 122763C-2R-1.

In the post-rift sediments of the Cretaceous Exmouth Plateau, terrigenous particles are significantly smaller than those in the Triassic Wombat Plateau sequence (Fig. 2D). Organic particles with a grain size exceeding $30 \mu \mathrm{m}$ were found neither in the Lower Cretaceous samples nor in the Cenomanian/Turonian black shales. A similar size distinction of organic particles was observed in pre-rift relative to postrift deep-sea sediments from Leg 103 on the Galicia continental margin off Portugal (Stein et al., 1988). The trend toward smaller grain sizes, according to Cornford (1979) and Cornford et al. (1980), can be explained as reflecting an increasingly more distal depositional setting with respect to the source(s) of the land plant particles. This interpretation is consistent with the general sedimentological scenario off northwest Australia, which indicates shallow marine deposition during the Triassic and a pelagic environment in the Cretaceous (Haq, von Rad, O'Connell, et al., 1990).

In the Cenomanian/Turonian black shales at Site 763 (for a core photo see fig. 10 on p. 301 of Shipboard Scientific Party, 1990a), bituminite and phytoplankton-derived alginite and liptodetrinite predominate over terrigenous macerals. In samples from the lower, very thin black shale (Sample 122-763C$2 \mathrm{R}-1,61-63 \mathrm{~cm}$ ) and the uppermost part of the somewhat thicker, shallower black shale (Sample 122-763C-2R-1, 19-21 $\mathrm{cm})$, whose organic carbon contents vary between $2 \%$ and $3 \%$, alginite and liptodetrinite are more abundant than bituminite. Conversely, the latter maceral type predominates in the central (Sample 122-763C-2R-1, 24-26 cm) and lower parts (Sample 122-763-2R-1, 28-30 cm) of the shallower black shale. This kind of bituminite enrichment has been found before-for example, in Cenomanian/Turonian black shales in the deep Atlantic Ocean at Site 603 off Cape Hatteras (Rullkötter et al., 1987) and Site 641 off Portugal (Stein et al., 1988). In both cases the organic carbon contents exceed $10 \%$. The same maceral characteristics also apply to Cenomanian/Turo- 
Table 2. Depth, age, and lithology of Wombat Plateau and Exmouth Plateau samples investigated in detail.

\begin{tabular}{|c|c|c|c|}
\hline $\begin{array}{l}\text { Core, section, } \\
\text { interval }(\mathrm{cm})\end{array}$ & $\begin{array}{l}\text { Depth } \\
\text { (mbsf) }\end{array}$ & Age & Lithology \\
\hline \multicolumn{4}{|l|}{ 122-759B- } \\
\hline $11 \mathrm{R}-2,66-70$ & 90.14 & Carnian & $\begin{array}{l}\text { Limestone with claystone fragments, light gray, } \\
\text { bioturbated }\end{array}$ \\
\hline $19 \mathrm{R}-2,28-38$ & 165.78 & Carnian & Silty claystone, dark gray, massive, soft \\
\hline $39 \mathrm{R}-3,57-62$ & 302.07 & Carnian & Silty claystone, medium dark gray, bioturbated \\
\hline \multicolumn{4}{|l|}{$122-760 \mathrm{~A}-$} \\
\hline $13 \mathrm{X}-1,41-49$ & 112.61 & Norian & Silty claystone, black, soft \\
\hline \multirow{2}{*}{\multicolumn{4}{|c|}{$140-147$}} \\
\hline & & Norian & \\
\hline \multicolumn{4}{|l|}{$122-760 \mathrm{~B}-$} \\
\hline 7R-1, 95-99 & 293.45 & Norian & Silty claystone, gray \\
\hline $8 \mathrm{R}-\mathrm{CC}, 16-21$ & 306.47 & Norian & Silty claystone, gray \\
\hline $16 \mathrm{R}-4,108-115$ & 430.27 & Norian & Siltstone, medium light gray \\
\hline \multicolumn{4}{|l|}{ 122-761C- } \\
\hline $31 \mathrm{R}-2,148-150$ & 411.18 & Rhaetian & Marlstone, dark gray \\
\hline \multicolumn{4}{|l|}{$122-762 \mathrm{C}$. } \\
\hline $79 X-2,139-142$ & 841.39 & lower Aptian & Silty claystone, black \\
\hline $81 X-3,74-81$ & 852.24 & lower Valanginian & Silty claystone, gray \\
\hline $82 X-2,130-137$ & 856.30 & upper Berriasian & Silty claystone, black \\
\hline \multicolumn{4}{|l|}{$122-763 \mathrm{C}-$} \\
\hline 2R-1, 19-21 & 385.20 & Cenomanian-Turonian & Claystone, black, bioturbated \\
\hline $2 \mathrm{R}-1,24-26$ & 385.25 & Cenomanian-Turonian & Claystone, black, laminated \\
\hline $2 \mathrm{R}-1,28-30$ & 385.28 & Cenomanian-Turonian & Claystone, black, laminated \\
\hline $2 \mathrm{R}-1,44-46$ & 385.45 & Cenomanian-Turonian & Claystone, green, mottled \\
\hline $2 \mathrm{R}-1,61-63$ & 385.62 & Cenomanian-Turonian & Claystone, black, bioturbated \\
\hline $2 \mathrm{R}-1,71-73$ & 385.72 & Cenomanian-Turonian & Claystone, green, mottled \\
\hline $2 \mathrm{R}-1,88-90$ & 385.89 & Cenomanian-Turonian & Clayey nannofossil chalk, white-green, mottled \\
\hline \multicolumn{4}{|l|}{ 122-763B- } \\
\hline $46 X-6,77-82$ & 615.56 & lower Aptian & Claystone, gray \\
\hline \multicolumn{4}{|l|}{$122-763 \mathrm{C}-$} \\
\hline $8 \mathrm{R}-3,16-23$ & 673.76 & upper Berriasian & Claystone, gray \\
\hline $29 \mathrm{R}-6,34-42$ & 873.44 & $\begin{array}{l}\text { middle-upper } \\
\text { Berriasian }\end{array}$ & Claystone, gray \\
\hline \multicolumn{4}{|l|}{$123-765 \mathrm{C}-$} \\
\hline $45 \mathrm{R}-4,100-104$ & 773.72 & lower Aptian & Claystone, black and light gray layers \\
\hline
\end{tabular}

nian boundary event (CTBE) black shales in the Tarfaya basin onshore Morocco (R. Littke, pers. comm., 1990).

Vitrinite reflectance values in all Cretaceous Exmouth Plateau sediments are lower than $0.3 \%$ (Fig. 4D), indicating a low degree of thermal stress. Qualitative fluorescence observations revealed brightly fluorescing alginite or liptodetrinite particles in support of the low-maturity interpretation.

Extract yields of most of the Lower Cretaceous sediments from the Exmouth Plateau were as low as those of the Triassic sediments from the Wombat Plateau, supporting the evidence of a similar organic matter type in both areas. Exceptions are the Berriasian Samples 122-763C-8R-3, 16-23 cm, and 122763C-29R-6, 34-42 cm (13.7 and $17.6 \mathrm{mg}$ extract/g $\mathrm{C}_{\text {org }}$, respectively), which is consistent with their elevated hydrogen indexes above $150 \mathrm{mg}$ hydrocarbons/g $\mathrm{C}_{\text {org }}$ and their higher liptinite content. The extract values of the Berriasian sediments thus are close to those of deep-sea sediments containing lipid-rich marine organic matter at a low level of thermal maturity (e.g., Rullkötter et al., 1981).

The bitumens of the Lower Cretaceous sediments are dominated by long-chain wax alkanes of higher land plant origin with a maximum at $n-\mathrm{C}_{27}$ and a strong predominance of the odd carbon number homologs (Fig. 7A, -B). The Berriasian samples also contain long-chain normal fatty acids of the same origin and with a carbon number maximum at $\mathrm{C}_{26}$ or $\mathrm{C}_{28}$ (Fig. 7B). In addition, all Lower Cretaceous samples contain a series of normal 1-alcohols and 2-ketones. This observation suggests that the liptinitic material present in these sediments is terrigenous; part of the compounds mentioned may be cutin hydrolysis products. It is interesting to note the presence of simonellite in the lower Valanginian (Fig. 7A) and middle-upper Berriasian samples, whereas it is not present in the upper Berriasian sample studied (Fig. 7B). The concentration of this compound is particularly high in Sample 122-763C-29R-6, 34-42 cm (middle-upper Berriasian), where it approaches the concentration of the dominant long-chain $n$-alkanes. Simonellite is a diterpenoid possibly of an origin similar to that of retene in the Triassic Wombat Plateau sediments but less aromatized. This difference is in accordance with the better preservation of the terrestrial organic matter in the Lower Cretaceous samples. Hopanoid hydrocarbons show a slightly different distribution compared to the Wombat Plateau sediments. In particular, the resistant neohop13(18)-ene is not dominant here and less abundant than the more labile hop-17(21)-ene. 
Table 3. Percentages of terrigeneous, marine, and total macerals and total pyrite as volume percent of whole rock.

\begin{tabular}{|c|c|c|c|c|c|c|c|c|c|c|}
\hline \multirow{2}{*}{$\begin{array}{l}\text { Core, section, } \\
\text { interval }(\mathrm{cm})\end{array}$} & \multicolumn{4}{|c|}{ Terrigenous macerals } & \multicolumn{3}{|c|}{ Marine macerals } & \multirow{2}{*}{$\begin{array}{c}\text { Total } \\
\text { macerals }\end{array}$} & \multirow{2}{*}{$\begin{array}{l}\text { Total } \\
\text { pyrite }\end{array}$} & \multirow{2}{*}{$\begin{array}{c}\text { Small }^{\mathrm{a}} \\
(<30 \mu \mathrm{m})\end{array}$} \\
\hline & Vitrinite & Inertinite & Sporinite & Cutinite & Bituminite & Liptodetrinite & Alginite & & & \\
\hline \multicolumn{11}{|l|}{ 122-759B- } \\
\hline $19 \mathrm{R}-2,28-38$ & 3.0 & 1.3 & 0.7 & 0 & 0 & 0 & 0.3 & 5.3 & 1.0 & 92 \\
\hline $39 \mathrm{R}-3,57-62$ & 3.3 & 1.3 & 0.7 & 0 & 0 & 0.3 & 0.3 & 5.9 & 0.3 & 91 \\
\hline \multicolumn{11}{|l|}{$122-760 \mathrm{~A}-$} \\
\hline $13 X-1,41-49$ & 2.6 & 1.6 & 0 & 0 & 0 & 0 & 0 & 4.2 & 0.6 & 95 \\
\hline $25 X-5,140-147$ & 0 & 0.6 & 0 & 0 & 0 & 0 & 0.3 & 0.9 & 0 & 100 \\
\hline $30 \mathrm{X}-3,121-128$ & 1.0 & 2.0 & 0 & 0.6 & 0 & 0 & 0.3 & 3.9 & 0.3 & 96 \\
\hline \multicolumn{11}{|l|}{$122-760 \mathrm{~B}-$} \\
\hline 7R-1, 95-99 & 5.0 & 6.0 & 0.7 & 0.3 & 0 & 0.3 & 0.3 & 12.6 & 1.7 & 77 \\
\hline $8 \mathrm{R}-\mathrm{CC}, 16-21$ & 2.3 & 0.6 & 0.3 & 0.6 & 0 & 0 & 0.6 & 4.4 & 1.9 & 86 \\
\hline $16 \mathrm{R}-4,108-115$ & 1.3 & 2.0 & 0.7 & 0.3 & 0 & 0.3 & 0.3 & 4.9 & 0.3 & 69 \\
\hline \multicolumn{11}{|l|}{$122-761 C$ - } \\
\hline $31 \mathrm{R}-2,148-150$ & 0 & 0.3 & 0 & 0 & 0 & 0 & 0 & 0.3 & 2.3 & 100 \\
\hline \multicolumn{11}{|l|}{$122-762 C-$} \\
\hline $79 \mathrm{X}-2,139-142$ & 0.7 & 0.3 & 0 & 0 & 0 & 0 & 0.7 & 1.7 & 0.3 & 100 \\
\hline $81 X-3,74-81$ & 1.0 & 0 & 1.3 & 0 & 0 & 0.3 & 0.6 & 3.2 & 1.6 & 100 \\
\hline $82 X-2,130-137$ & 0.3 & 0.3 & 0.6 & 0 & 0 & 0 & 0.6 & 1.8 & 3.3 & 100 \\
\hline \multicolumn{11}{|l|}{$122-763 \mathrm{C}$} \\
\hline 2R-1, 19-21 & 0.3 & 0.7 & 0 & 0 & 1.3 & 2.3 & 2.0 & 6.6 & 2.3 & 100 \\
\hline $2 \mathrm{R}-1,24-26$ & 0 & 0.3 & 0 & 0 & 6.6 & 4.7 & 5.7 & 17.3 & 3.0 & 100 \\
\hline $2 \mathrm{R}-1,28-30$ & 0 & 0 & 0.3 & 0 & 27.0 & 4.7 & 7.7 & 39.7 & 1.6 & 100 \\
\hline $2 \mathrm{R}-1,44-46$ & 0 & 0 & 0 & 0 & 0 & 0 & 0.3 & 0.3 & 2.0 & 100 \\
\hline $2 \mathrm{R}-1,61-63$ & 0.3 & 0 & 0 & 0 & 1.3 & 1.3 & 1.0 & 3.9 & 1.3 & 100 \\
\hline $2 \mathrm{R}-1,71-73$ & 0.3 & 0 & 0.3 & 0 & 0 & 0 & 0 & 0.6 & 1.4 & 100 \\
\hline $2 \mathrm{R}-1,88-90$ & 0 & 0 & 0 & 0 & 0 & 0 & 0 & 0 & 1.3 & 100 \\
\hline \multicolumn{11}{|l|}{$122-763 \mathrm{~B}-$} \\
\hline $46 \mathrm{X}-6,77-82$ & 0.6 & 0 & 0.3 & 0 & 0 & 0 & 0.3 & 1.2 & 2.6 & 100 \\
\hline $8 \mathrm{R}-3,16-23$ & 0.3 & 0 & 1.0 & 0 & 0 & 0 & 0.3 & 1.6 & 3.2 & 100 \\
\hline $29 \mathrm{R}-6,34-42$ & 0.3 & 1.6 & 0.3 & 0 & 0 & 0 & 2.0 & 4.2 & 2.0 & 100 \\
\hline \multicolumn{11}{|l|}{$123-765 \mathrm{C}-$} \\
\hline $45 \mathrm{R}-4,100-104$ & 0.6 & 0 & 0 & 0 & $b_{6.0}$ & 1.3 & 1.3 & 9.2 & 4.0 & 100 \\
\hline
\end{tabular}

aPercentage of vitrinite and inertinite particles smaller than $30 \mu \mathrm{m}$.

bmall bituminite or dark vitrinite?

The relative concentrations of $n$-alkanes are lower in the Cenomanian/Turonian boundary sediments from Site 763 (Fig. $8 \mathrm{~A},-\mathrm{B})$ than in the Lower Cretaceous and Triassic sediments discussed before. They still can be readily identified in the total extracts of the uppermost two samples of the shallower black shale layer (Fig. 8A), whereas they are virtually absent in the most organic-carbon-rich basal part of this layer. Where recognizable, short-chain $n$-alkanes of algal origin with a maximum at $n-C_{17}$ and a dominance of the odd carbon number homologs are more abundant than long-chain wax alkanes.

Straight-chain fatty acids are the most abundant class of compounds identified in Sample 122-763C-2R-1, 28-30 cm (Fig. 8B), the most organic-carbon-rich black shale studied $\left(25.9 \% \mathrm{C}_{\mathrm{org}}\right)$. Surprisingly, only long-chain acids in the range of $n-C_{20}$ to $n-C_{32}$ were detected. Considering the pyrolysis and maceral analysis results, it is hard to believe that these are of terrigenous origin. It is more likely that these fatty acids are of bacterial origin. The very low abundance of shorter chain acids in Sample 122-763C-2R-1, 28-30 cm, is also difficult to explain at the moment. They are more abundant in the other three Cenomanian/Turonian black shale samples, where they predominate over the long-chain homologs.

Several of the most abundant single components in the gas chromatograms of the Cenomanian black shales could not yet be identified; some of them may be alcohols as indicated by a fragment at $\mathrm{m} / \mathrm{z} 73$ in the mass spectra (e.g., homologous compounds $\mathrm{u}^{\prime}$ and $\mathrm{z}^{\prime}$ in Sample 122-763C-2R-1, 28-30 cm). Assigned or suspected contaminants (plasticizers) vary in their distribution patterns and, as expected, are less abundant in the organic-carbon-rich black shales. The significance of some of these compounds thus remains unclear.

Steroids are present in all four black shale samples. They range from steranes $\left(\mathrm{C}_{27}-\mathrm{C}_{29}\right.$, low relative abundance) and sterenes (particularly ster-4-enes and ster-5-enes), particularly abundant in the deeper black shale layer (i.e., Sample 122-763C-2R-1, 61-63 cm), to steroidal alcohols and ketones. A 4,24-dimethylsterol is one of the most abundant steroids in the most organic-carbon-rich black shale sample. This compound may be of dinoflagellate origin (Robinson et al., 1984). No specific compound assignments could be made, however, in the gas chromatograms (Fig. 8) due to the complexity of the molecular mixture in the high-molecular weight range. Further identifications will only be possible after liquid chromatographic separation of the extracts and reanalysis by GC-MS. The preservation of a variety of the relatively labile steroids is consistent with the overall enhanced level of organic matter preservation in the black shales and the detection of liptinitic material by maceral analysis under the microscope. Although microbial activity has been deduced from the presence of bituminite, bacterial hopanoids are not major constituents of 

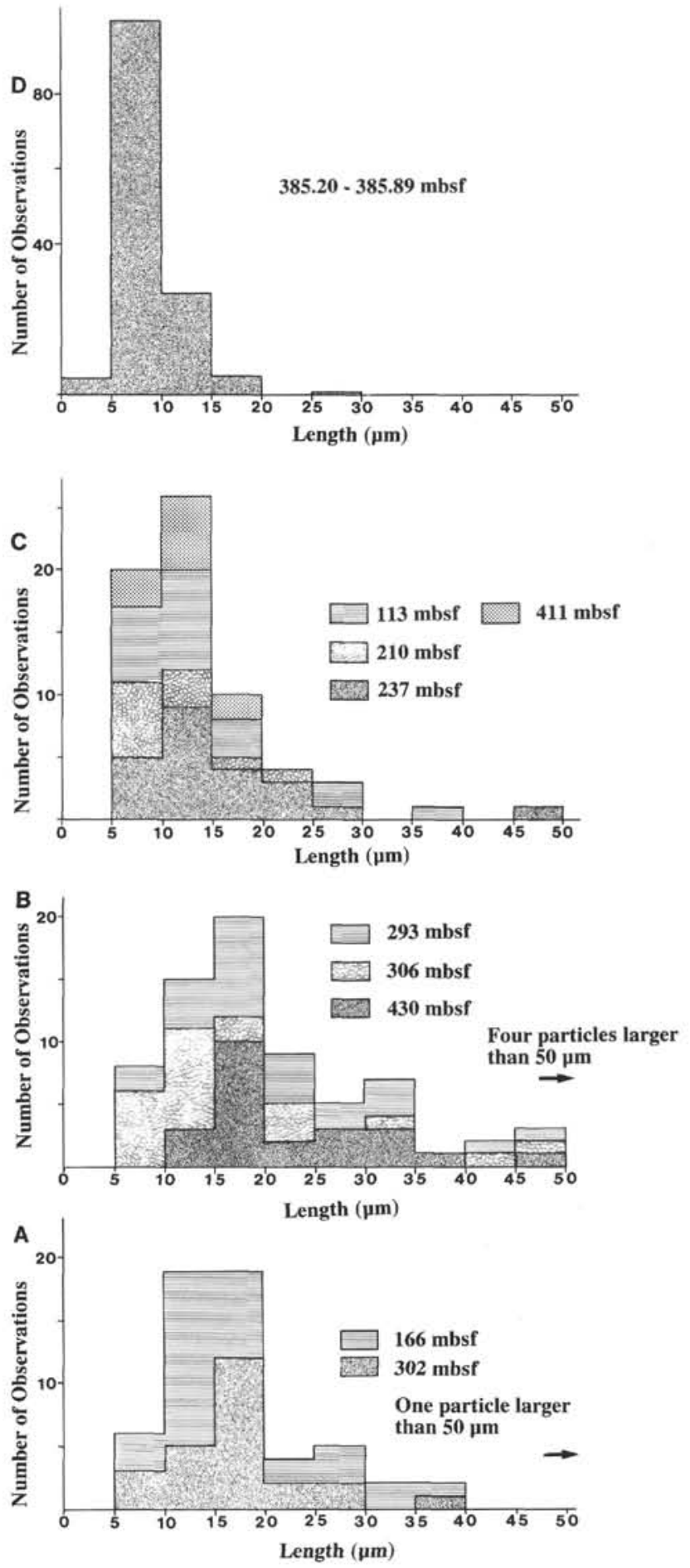

Figure 2. Distribution of particle size of terrigenous macerals for four selected sediments from the Cretaceous (Exmouth Plateau) and the Triassic (Wombat Plateau). Data are combined for relevant samples listed in Table 2 in each case. A. Site 760, Triassic (Norian), and Site 761, Triassic (Rhaetian). B. Site 760 (upper Carnian-lower Norian). C. Site 759, Triassic (lower-middle Carnian). D. Site 763, Cretaceous (Cenomanian/Turonian). the extractable organic matter of the black shales. The $17 \beta(\mathrm{H}), 21 \beta(\mathrm{H})$-homohopane $\left(\mathrm{I}^{\prime}\right)$ is the most abundant single hopanoid in each case.

\section{Argo Abyssal Plain (Cretaceous)}

Selected samples from Site 765 in the Argo Abyssal Plain were investigated to find out if black shale deposition extended from the continental margin farther offshore. The Cenomanian/Turonian samples (Sections 123-765C-24R-2 and 123-765C-26R-1) apparently are typical open-marine deposits with very low organic carbon contents. The lower Aptian sediment (Sample 123-765C-45R-4, 100-104 cm), despite its richness in organic matter $\left(4.35 \% \mathrm{C}_{\text {org }}\right)$, can hardly be regarded as a typical black shale. The low hydrogen index value is consistent with the microscopic observation of dark-reflecting, non-fluorescent organic particles in this sample, which may be oxidized bituminite or vitrinite. The small size of the sample prevented an unequivocal identification, and thus the significance of this organic matter enrichment in the abyssal plain remains unclear at the moment.

The gas chromatogram of the extractable organic matter of the lower Aptian sample (Fig. 9) exhibits bimodal distributions of $n$-alkanes as well as normal fatty acids with the short-chain components dominating in both cases. Together with the presence of steroids (hydrocarbons, alcohols, and ketones) this mixture should indicate the incorporation of a significant amount of marine organic matter into the sediment, although this interpretation is inconsistent with the low hydrogen index value and the result of the maceral analysis. A possible explanation could be that a low proportion of marine organic matter is overrepresented in the extract because the bulk of the organic matter, which appeared to be altered under the microscope, yields extremely little extractable material.

\section{Cenomanian/Turonian Black Shale Formation}

The occurrence of black shales rich in organic matter at the Cenomanian/Turonian boundary in many places of the world's oceans (including locations presently on the continents) has been associated with an oceanwide anoxic event of which causes and details of the consequential paleoenvironmental conditions of deposition are still not clear (e.g., Schlanger and Jenkyns, 1976; Herbin et al., 1986; Arthur et al., 1987, Schlanger et al., 1987). On the northwest Australian continental margin, Cenomanian/Turonian boundary sediments were recovered at Sites $763,762,765$, and 766 . Typical marine black shales (see Waples, 1983, for definition) occur only at Site 763 on the Exmouth Plateau, where the organic carbon content exceeds $25 \%$ (Table 1). At the nearby Site 762 (approximately the same water depth at present), organic carbon contents in the stratigraphically equivalent sediments do not exceed 2\% (Haq, von Rad, O'Connell, et al., 1990). At Site 765 in the Argo Abyssal Plain, a few distinct layers of black, faintly laminated shale occur near the Turonian/Cenomanian boundary, but organic carbon values are within the low limits of typical open-ocean deposits (Table 1; Shipboard Scientific Party, 1990b). Light colors of the equivalent sediments at Site 766 (foot of Exmouth Plateau toward Gascogne Abyssal Plain) indicate neither strongly reducing conditions nor incorporation of significant amounts of organic matter (Shipboard Scientific Party, 1990c).

The composition of the organic matter in the two richest samples from Hole 763C (Table 1) is similar to that in Atlantic Ocean Cenomanian/Turonian black shales (e.g., Rullkötter et al., 1987; Stein et al., 1988). There is a high concentration of structurally degraded organic matter (bituminite), that is, particles with a shape not corresponding to cellular structures of the precursor organisms. A controversy exists as to the possible 


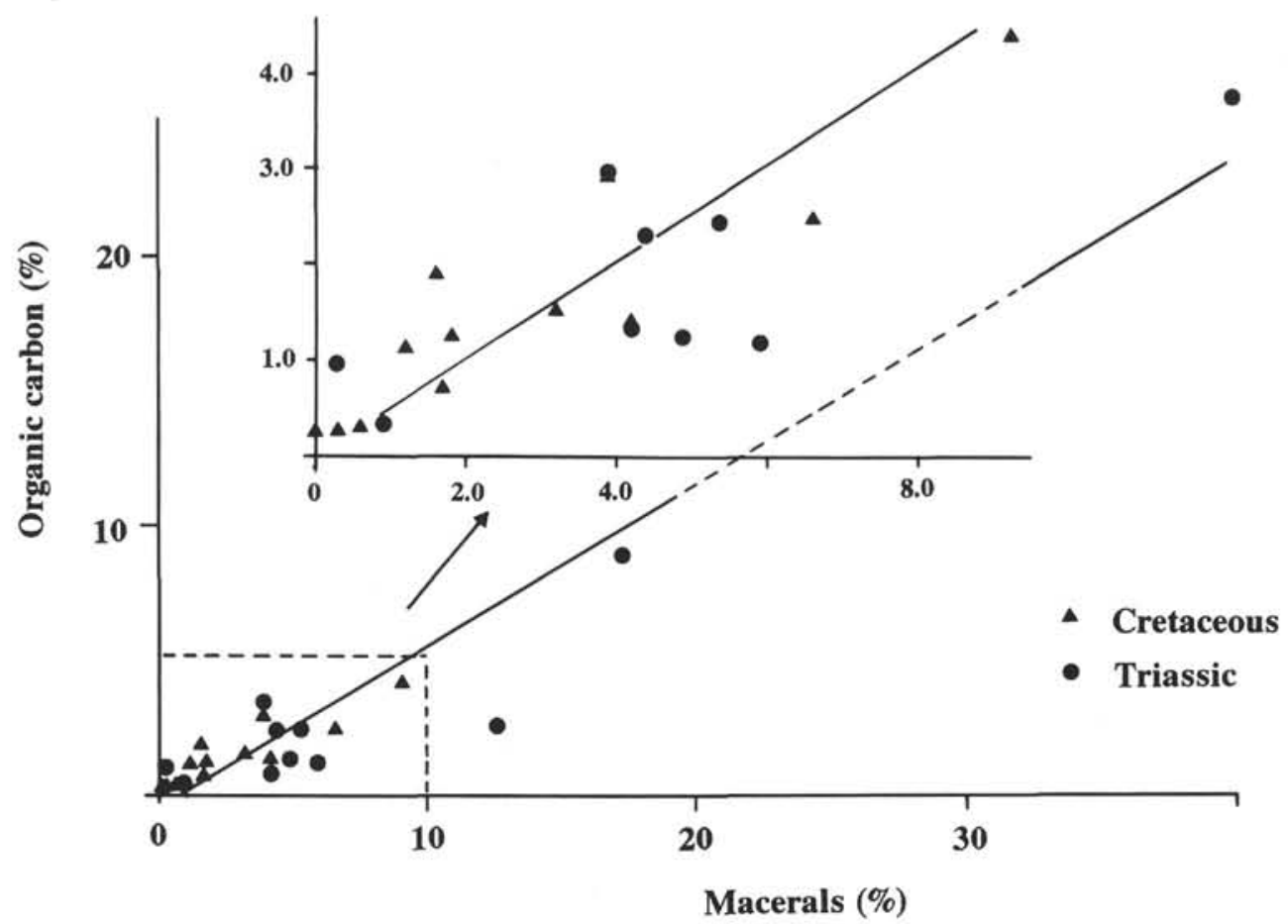

Figure 3. Relationship between total organic carbon weight percent and volume percent of organic macerals in total rock indicating that in ODP Leg 122 sediments, almost all of the organic matter could be recognized under the microscope (see text for further explanation).

origin of bituminite particles. According to Teichmüller (in Stach et al., 1982), these are anaerobic microbial alteration products formed after deposition in the sediments. In contrast to this, Littke and Rullkötter (1987) favor the hypothesis that bituminite has a fecal pellet origin. In any case, structural degradation (in terms of a disintegration on a macromolecular or cellular level, not necessarily on a monomolecular level) in this case is thought to be mainly a biological process which does not involve significant oxidation by molecular oxygen during subaerial transport or in the water column.

A second common bulk characteristic of the organic matter in the rich Cenomanian/Turonian black shales on the northwest Australian continental margin, as well as other deep-sea locations, is the only moderately high hydrogen index (350-450 mg hydrocarbons/g $C_{\text {org }}$ ). We believe that this is related to the paleowater depth under which these black shales were deposited, because such moderately high hydrogen indexes are uncommon for sediments containing high amounts of organic matter (e.g., Tissot and Welte, 1984; Rullkötter et al., 1988), except for coals of terrestrial higher plant origin. The idea is that deposition at great water depths implies an extended food chain and thus a relatively extensive hydrogen depletion of materials which ultimately constitute the preserved fecal pellets. At the same time the percentage of well-preserved cellular structures of decayed organisms is smaller in deep-sea sediments than in shallow epicontinental sea sediments at similar levels of organic richness (see, for example, Littke and Rullkötter, 1987).

Because sedimentation rates were low at the time of deposition of Cenomanian/Turonian boundary sediments (Shipboard Scientific Party, 1990a, 1990b, 1990c), preservation of high amounts of organic matter requires anoxic bottom-water conditions (Stein, 1986). They need not have been as extended as in the modern Black Sea because travel time of (relatively large) fecal pellets through the oxygenated water column will be relatively short, and, thus, at low sedimentation rates, degradation processes during the long residence time near the sediment/ water interface are more important than those in the water column. This is consistent with observations of Stein (1986) and Stein et al. (1986) in the Atlantic Ocean. The cause of formation of oxygen-depleted bottom-water masses is still unknown, but the common sedimentary characteristics of the fossil organic matter indeed suggest a global effect. Differences in organic matter accumulation between the different sites on the northwest Australian margin, based on this sequence of arguments, may be largely related to variations in primary bioproductivity in the surface waters.

In the case of the thicker (shallower) Cenomanian/Turonian boundary black shale layer in Hole 763C, black shale formation started more or less abruptly and later ceased gradually. This evolution is obvious from the higher organic carbon contents and greater hydrogen richness of the basal part of this black shale layer and a decrease of organic carbon contents and hydrogen indexes toward the top. Sediments between the two black shale layers, with respect to their organic matter characteristics, are typical background sediments as observed in the underlying Lower Cretaceous section. Although calcareous nannofossil stratigraphy indicates that the Cenomanian/Turonian boundary event is extremely condensed at Sites 762 and 763 , there is no evidence for a break in sedimentation across the Cenomanian/ Turonian boundary (Bralower and Siesser, this volume), although this is not undisputed (U. von Rad, pers. comm., 1990). A sharp basal contact of black shale deposition and a transitional upper boundary is not uncommon. One possible reason for such a feature is a sudden increase of primary marine bioproductivity as a consequence of increased terrigenous nutrient supply after a marine transgression (Wenger and Baker, 1986). There is no indication that this mechanism had an influence on marine organic matter preservation in the Cenomanian/Turonian black shales on the northwest Australian continental margin. 

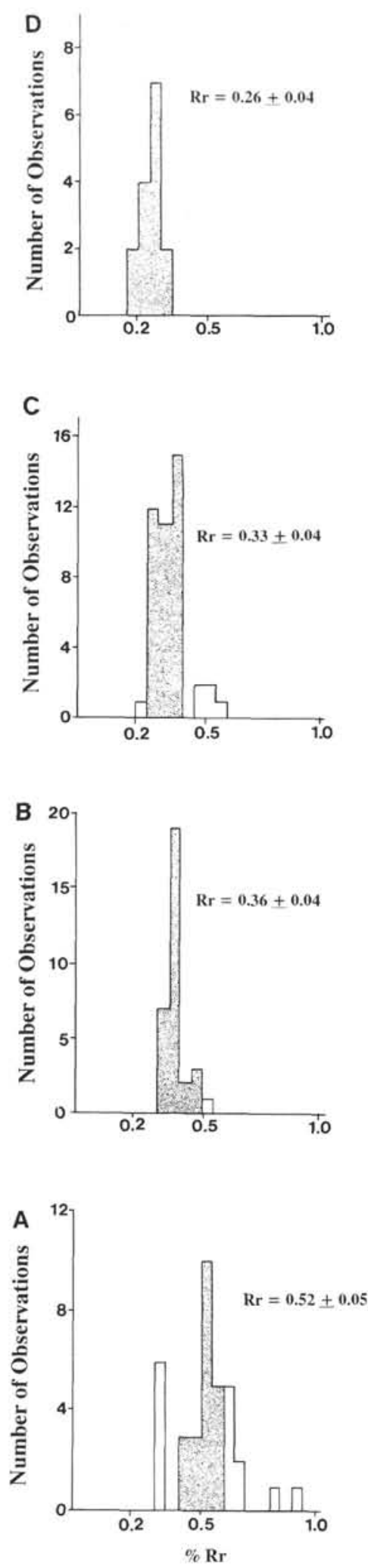

Figure 4. Vitrinite reflectance histograms of Cretaceous (Exmouth Plateau) and Triassic sediments (Wombat Plateau) from the northwest Australian continental margin. A. Sample 122-759B-39R-3, 57-62 cm (302.07 mbsf), Triassic. B. Sample 122-760B-8R-CC, 16-21 cm (306.47 mbsf), Triassic. C. Sample 122-760B-7R-1, 95-99 cm (293.45 mbsf), Triassic. D. Sample 122-763C-2R-1, 24-26 cm (385.25 mbsf), Cretaceous (CTBE).

\section{Source Rock Potential}

The offshore northwest Australian continental margin area investigated during Legs 122 and 123 is part of the Carnarvon Basin (Purcell and Purcell, 1988b). While a major gas-condensate and several small oil discoveries were made and put under production in the Barrow-Dampier and Exmouth sub-basins (Woodside Offshore Petroleum, 1988; Parry and Smith, 1988), exploration on the Exmouth Plateau frontier area has not been commercially successful so far (Barber, 1988). Triassic and Jurassic rocks are considered the main sources of the hydrocarbons discovered in the sub-basins, while Lower Cretaceous and younger sediments are immature (Woodside Offshore Petroleum, 1988; Parry and Smith, 1988). In the Exmouth Plateau area, the anoxic conditions of the sub-basins were missing at these times and an open-marine depositional environment prevented the accumulation of oil-prone source rocks (Barber, 1988). Prolonged periods of erosion during the Jurassic added to the unfavorable conditions on the Exmouth Plateau.

Cook et al. (1985) demonstrated the possibility of minor light oil generation within the fluviodeltaic section of the Mungaroo Formation (Upper Triassic) based on the presence of liptodetrinite, cutinite, sporinite, and resinite. In the Triassic sediments recovered during Leg 122 , these macerals are subordinate or absent, and the hydrogen-lean vitrinites and inertinites have no substantial hydrocarbon generation potential.

The Berriasian section at Site 763 may be a (less prolific) equivalent of the more landward Neocomian active source rocks (Cook et al., 1985; Exon and Willcox, 1978, 1980). The Cenomanian/Turonian black shale layers are the only rocks containing oil-prone organic matter, but their small thickness prevents them from being realistic hydrocarbon sources. In any case the maturity of the organic matter in the Cretaceous sediments, as in the Barrow-Dampier and Exmouth subbasins further onshore, is too low for the onset of thermal hydrocarbon generation.

\section{CONCLUSIONS}

Preliminary investigation of deep-sea sediments from the northwest Australian continental margin revealed that terrigenous organic matter supply is a major factor in the Triassic sequence on the Wombat Plateau and in the Cretaceous sequence on the Exmouth Plateau. Marine organic matter occurrence is restricted to a couple of thin Cenomanian/ Turonian black shales at Site 763, whereas Tertiary sediments are virtually devoid of organic matter. Cenomanian/Turonian black shales at locations other than Site 763 are considerably less rich in organic matter that is also less hydrogen-rich.

Terrigenous organic matter mainly consists of vitrinites and inertinites; only Berriasian sediments at Site 763 are significantly enriched in liptinites. Particle-size distribution of the macerals of terrestrial origin reflects the depositional environment; that is, shallow-water nearshore deltaic deposition in the Triassic (larger particles) and pelagic sedimentation in the Cretaceous (small particles). Marine organic matter in the Cenomanian/Turonian black shale is largely structurally degraded (bituminite) and possibly originating from fecal pellets. The moderate hydrogen richness (as evident from Rock-Eval pyrolysis) indicates significant biological oxidation in the food chain. Deposition then may have occurred by rapid sinking of the fecal pellets from a surface-water zone with a reasonably high bioproductivity (at Site 763) through mostly oxygenated water masses into an oxygen-depleted bottom-water mass. This bottom-water mass may be a consequence of a worldwide Cenomanian/Turonian boundary event the causes of which are still unclear. The reason for the variations in the organic matter characteristics of the Cenomanian/Turonian boundary black shales is thought to be 

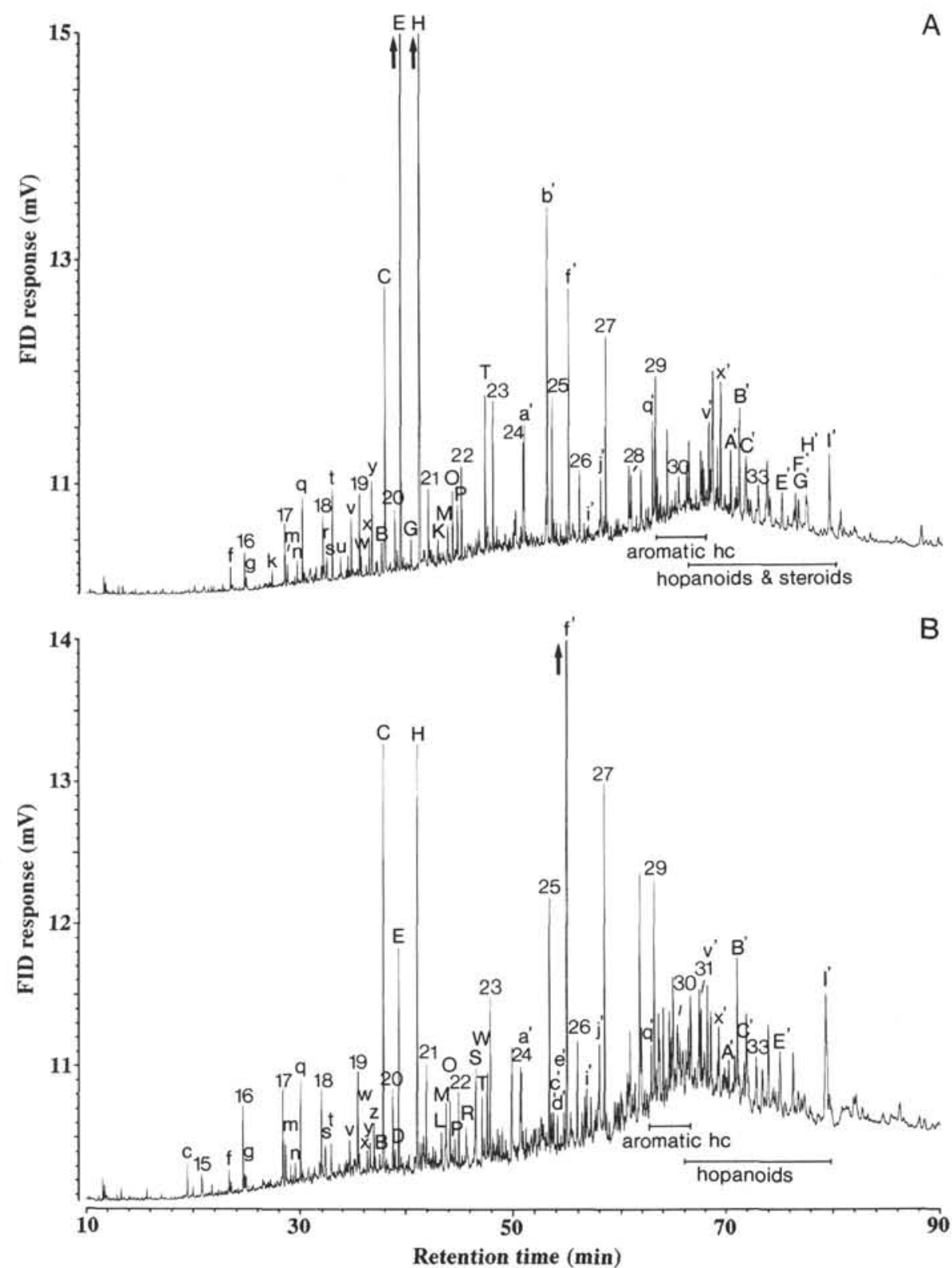

Figure 5. Capillary column gas chromatograms of the total extracts of two representative Triassic sediments from the Wombat Plateau. Numbers indicate $n$-alkanes. Lettered compounds are listed in Table 4. A. Sample 122-760B-8R-CC, $16-21 \mathrm{~cm}\left(306.47 \mathrm{mbsf} ; 2.28 \% \mathrm{C}_{\text {org }}\right)$. B. Sample 122-759B-39R-3, 57-62 cm (302.07 mbsf; $\left.1.17 \% \mathrm{C}_{\text {org }}\right)$.

mainly the result of differences in primary bioproductivity at the different locations.

Molecular analysis of total extractable material revealed abundant long-chain $n$-alkanes in those samples containing terrigenous organic matter only. Sediments with marine organic matter exhibit high relative concentrations of $n$-fatty acids and steroidal compounds. An in-depth interpretation of the molecular composition of the extracts will require further liquid chromatographic separation.

\section{ACKNOWLEDGMENTS}

We are grateful to Prof. P. A. Meyers (University of Michigan, Ann Arbor) for selecting appropriate samples for this study aboard the JOIDES Resolution. The authors thank W. Benders, E. Biermanns, A. Fischer, R. Harms, J. Höltkemeier, B. Kammer, F. J. Keller, H. Schnitzler, M. Sostmann, and $\mathrm{H}$. Willsch for various kinds of technical support. Critical comments by K. Emeis (Universität Kiel), K. A. Kvenvolden (U.S. Geological Survey, Menlo Park), and U. von Rad (BGR, Hannover) were highly appreciated. The study was financially supported by the Deutsche Forschungsgemeinschaft, grant nos. We $346 / 27$ and $\mathrm{Ru} 458 / 1$.

\section{REFERENCES}

Arthur, M. A., Schlanger, S. O., and Jenkyns, H. C., 1987. The Cenomanian-Turonian oceanic anoxic event, II. Palaeoceanographic controls on organic-matter production and preservation. In Brooks, J., and Fleet, A. J. (Eds.), Marine Petroleum Source Rocks. Geol. Soc. London Spec. Publ., 26:401-420.

Barber, P. M., 1988. The Exmouth Plateau deep water frontier: a case history. In Purcell, P. G., and Purcell, R. R. (Eds.), The North West Shelf, Australia: Proc. Pet. Expl. Soc. Aust. Symp., 173-187. 
Boillot, G., Winterer, E. L., Meyer, A. W., et al., 1987. Proc. ODP, Init. Repts., 103: College Station, TX (Ocean Drilling Program).

Brassell, S. C., Comet, P. A., Eglinton, G., Isaacson, P. J., McEvoy, J., Maxwell, J. R., Thomson, I. D., Tibbetts, P. J., and Volkman, J. K., 1980. The origin and fate of lipids in the Japan Trench. In Douglas, A. G., and Maxwell, J. R., Advances in Organic Geochemistry 1979: Oxford (Pergamon Press), 375-392.

Cook, A. C., Smyth, M., and Vos, R. G., 1985. Source potential of Upper Triassic fluvio-deltaic systems of the Exmouth Plateau. APEA J., 25:204-215.

Cornford, C., 1979. Organic petrography of Lower Cretaceous shales at DSDP Site 398, Vigo Seamount, eastern North Atlantic. In Sibuet J. C., Ryan, W.B.F., et al., Init. Repts. DSDP, 47 (Pt. 1): Washington (U.S. Govt. Printing Office), 523-527.

Cornford, C., Rullkötter, J., and Welte, D. H., 1980. A synthesis of organic petrographic and geochemical results from DSDP sites in the eastern central North Atlantic. In Douglas, A. G., and Maxwell, J. R., Advances in Organic Geochemistry 1979: Oxford (Pergamon Press), 445-453.

Eglinton, G., and Hamilton, R. J., 1963. The distribution of alkanes. In Swain, T. (Ed.), Chemical Plant Taxonomy: London (Academic Press), 187-208.

Exon, N. F., and Willcox, J. B., 1978. Geology and petroleum potential of the Exmouth Plateau area off Western Australia. AAPG Bull., 62:40-72.

1980. The Exmouth Plateau: stratigraphy, structure and petroleum potential. Bull. Bur. Miner. Resour. Geol. Geophys. Aust., 199:1-52.

Haq, B. U., von Rad, U., O'Connell, S., et al., 1990. Proc. ODP, Init. Repts, 122: College Station, TX (Ocean Drilling Program).

Herbin, J. P., Montadert, L., Mueller, C., Gomez, R., Thurow, J., and Wiedmann, J., 1986. Organic-rich sedimentation at the Cenomanian-Turonian Boundary in oceanic and coastal basins in the North Atlantic and Tethys. In Summerhayes, C. P., and Shackleton, N. J. (Eds.), North Atlantic Palaeoceanography. Geol. Soc. Spec. Publ. London, 22:389-422.

Littke, R., and Rullkötter, J., 1987. Mikroskopische und makroskopische unterschiede zwischen profilen unreifen und reifen Posidonienschiefers aus der Hilsmulde, Facies, 17:171-180.

Littke, R., Rullkötter, J., and Schaefer, R. G., in press. Organic and carbonate carbon accumulation on Broken Ridge and Ninetyeast Ridge, Central Indian Ocean. In Peirce, J., Weissel, J., et al., Proc. ODP, Sci. Results, 121: College Station (Ocean Drilling Program).

Ourisson, G., Albrecht, P., and Rohmer, M., 1979. The hopanoids: paleochemistry and biochemistry of a group of natural products. Pure Appl. Chem., 51:709-729.

Parry, J. C., and Smith, D. N., 1988. The Barrow and Exmouth sub-basins. In Purcell, P. G., and Purcell, R. R. (Eds.), The North West Shelf, Australia. Pet. Expl. Soc. Aust. Symp., 129-145.

Purcell, P. G., and Purcell, R. R. (Eds.), 1988a. The North West Shelf, Australia: Proc. Pet. Expl. Soc. Aust. Symp.

Purcell, P. G., and Purcell, R. R., 1988b. The Northwest Shelf Australia: an introduction. In Purcell, P. G., and Purcell, R. R. (Eds.), The North West Shelf Australia. Proc. Pet. Expl. Soc. Aust. Symp., 1-17.

Radke, M., Sittardt, H. G., and Welte, D. H., 1978. Removal of soluble organic matter from rock samples with a flow-through extraction cell. Anal. Chem., 50:663-665.

Robinson, N., Eglinton, G., Brassell, S. C., and Cranwell, P. A., 1984. Dinoflagellate origin for sedimentary $4 \alpha$-methylsteroids and $5 \alpha(\mathrm{H})$-stanols. Nature, 308:439-441.

Rullkötter, J., Leythaeuser, D., Horsfield, B., Littke, R., Mann, U., Müller, P. J., Radke, M., Schaefer, R. G., Schenk, H.-J., Schwochau, K., Witte, E. G., and Welte, D. H., 1988. Organic matter maturation under the influence of a deep intrusive heat source: a natural experiment for quantitation of hydrocarbon generation and expulsion from a petroleum source rock (Toarcian shale, northern Germany). In Mattavelli, L., and Novelli, L. (Eds.), Advances in Organic Geochemistry 1987: Oxford (Pergamon Press), 847-856.

Rullkötter, J., Mukhopadhyay, P. K., and Welte, D. H., 1987. Geochemistry and petrography of organic matter from Deep Sea Drilling Project Site 603, lower continental rise off Cape Hatteras.
In van Hinte, J. E., Wise, S. W., Jr., et al., Init. Repts. DSDP, 93: Washington (U.S. Govt. Printing Office), 1163-1176.

Rullkötter, J., von der Dick, H., and Welte, D. H., 1981. Organic petrography and extractable hydrocarbons of sediments from the eastern North Pacific Ocean, Deep Sea Drilling Project Leg 63. In Yeats, R. S., Haq, B. U., et al., Init. Repts. DSDP, 63: Washington (U.S. Govt. Printing Office), 819-836.

Scheidt, G., and Littke, R., 1989. Comparative organic petrology of interlayered sandstones, siltstones, mudstones and coals in the Upper Carboniferous Ruhr basin, Northwest Germany, and their thermal history and methane generation. Geol. Rundsch., 78:375390.

Schlanger, S. O., Arthur, M. A., Jenkyns, H. C., and Scholle, P. A., 1987. The Cenomanian-Turonian Oceanic Anoxic Event, I. Stratigraphy and distribution of organic carbon-rich beds and the marine $\delta^{13} \mathrm{C}$ excursion. In Brooks, J., and Fleet, A. J. Marine Petroleum Source Rocks. Geol. Soc. Spec. Publ. London, 26:371-399.

Schlanger, S. O., and Jenkyns, H. C., 1976. Cretaceous oceanic anoxic events: causes and consequences. Geol. Mijnbouw, 55:179-184.

Shipboard Scientific Party, 1990a. Site 763. In Haq, B. U., von Rad, U., O'Connell, et al., Proc. ODP, Init. Repts., 122: College Station, TX (Ocean Drilling Program), 289-352. 1990b. Site 765. In Ludden, J. N., Gradstein, F. M., et al., Proc. ODP, Init. Repts., 123: College Station, TX (Ocean Drilling Program), 63-267.

1990c. Site 766. In Ludden, J. N., Gradstein, F. M., et al., Proc. ODP, Init. Repts., 123: College Station, TX (Ocean Drilling Program), 269-352.

Smyth, M., 1983. Nature of source material for hydrocarbons in Cooper Basin, Australia. AAPG Bull., 67:1422-1428.

Stach, E., Mackowsky, M. T., Teichmüller, M., Taylor, G. H., Chandra, D., and Teichmüller, R., 1982. Stach's Textbook of Coal Petrology (3rd ed.): Berlin (Gebrüder Borntraeger).

Stein, R., 1986. Organic carbon and sedimentation rates-further evidence for anoxic deep-water conditions in the Cenomanian/ Turonian Atlantic Ocean. Mar. Geol., 72:199-209.

Stein, R., Rullkötter, J., Littke, R., Schaefer, R. G., and Welte, D. H., 1988. Organofacies reconstruction and lipid geochemistry of sediments from the Galicia Margin, Northeast Atlantic (ODP Leg 103). In Boillot, G., Winterer, E. L., et al., Proc. ODP, Sci. Results, 103: College Station, TX (Ocean Drilling Program), 567-585.

Stein, R., Rullkötter, J., and Welte, D.H., 1986. Accumulation of organic-carbon-rich sediments in the Late Jurassic and Cretaceous Atlantic Ocean-a synthesis. Chem. Geol., 56:1-32.

ten Haven, H. L., Littke, R., Rullkötter, J., Stein, R., and Welte, D. H., 1990. Accumulation rates and composition of organic matter in late Cenozoic sediments underlying the active upwelling area off Peru. In Suess, E., von Huene, R., et al., Proc. ODP, Sci. Results, 112: College Station, TX (Ocean Drilling Program), 591-606.

Tissot, B. P., and Welte, D. H., 1984. Petroleum Formation and Occurrence (2nd ed.): Heidelberg (Springer-Verlag).

von Rad, U., Thurow, J., Haq, B. U., Gradstein, F., Ludden, J., and ODP Leg 122/123 Shipboard Scientific Parties, 1989. Triassic to Cenozoic evolution of the NW Australian continental margin and the birth of the Indian Ocean (preliminary results of ODP Legs 122 and 123). Geol. Rundsch., 78:1189-1210.

Waples, D. W., 1983. Reappraisal of anoxia and organic richness, with emphasis on Cretaceous of North Atlantic. AAPG Bull., 61:963-978.

Wenger, L. M., and Baker, D. R., 1986. Variations in organic geochemistry of anoxic-oxic black shales-carbonate sequences in the Pennsylvanian of the Midcontinent, U.S.A. In Leythaeuser, D., and Rullkötter, J. (Eds.), Advances in Organic Geochemistry 1985: Oxford (Pergamon Press), 85-92.

Woodside Offshore Petroleum, 1988. A review of the petroleum geology and hydrocarbon potential of the Barrow-Dampier sub-basin and environs. In Purcell, P. G., and Purcell, R. R. (Eds.), The North West Shelf, Australia Proc. Pet. Expl. Soc. Aust. Symp., 115-128.

Date of initial receipt: 3 August 1990

Date of acceptance: 20 February 1991

Ms 122B-135 
Table 4. Compounds detected in the extractable bitumens of sediments from Legs 122 and 123.

\begin{tabular}{|c|c|c|}
\hline Code & Compound & Mass spectral data $(\mathrm{m} / \mathrm{z})$ \\
\hline a & diethyleneglycol di-TMS ether & \\
\hline b & 3-ethyl-4-methyl-1H-pyrrole-2,5-dione & $139\left(\mathrm{M}^{+}, \mathrm{BP}\right), 124,110,96,67$ \\
\hline c & $2,6,10$-trimethyltridecane $\left(C_{16}\right.$ isoprenoid $)$ & {$\left[226, \mathrm{M}^{+}\right], 183,141,113,99,85,71$ (BP), 57} \\
\hline d & dodecanoic acid methylester & $214\left(\mathrm{M}^{+}\right), 87,74(\mathrm{BP})$ \\
\hline e & unknown & $188\left(\mathrm{M}^{+}\right), 173(\mathrm{BP})$ \\
\hline f & unknown & $356\left(\mathrm{M}^{+}\right), 341,325,296,244,221,207,147,75,73$ (BP) \\
\hline g & diethylphthalate & $222\left(\mathrm{M}^{+}\right), 177,149(\mathrm{BP})$ \\
\hline $\mathrm{h}$ & tridecanoic acid methylester & $228\left(\mathrm{M}^{+}\right), 87,74(\mathrm{BP})$ \\
\hline i & unknown & $182\left(\mathrm{M}^{+}\right), 105,77$ \\
\hline $\mathrm{j}$ & unknown & $202\left(\mathrm{M}^{+}\right), 187$ \\
\hline k & branched $\mathrm{C}_{13}$ alcohol TMS ether & $272\left(\mathrm{M}^{+}\right), 257,117,73(\mathrm{BP})$ \\
\hline 1 & unknown & $269,254,237,222,194,185,129$ (BP), $111,57,55$ \\
\hline $\mathrm{m}$ & pristane & \\
\hline $\mathbf{n}$ & tetradecanoic acid methylester & $242\left(\mathrm{M}^{+}\right), 87,74(\mathrm{BP})$ \\
\hline o & phthalic acid di-TMS ester & 295,147 (BP), 73 \\
\hline $\mathrm{p}$ & unknown & $202\left(\mathrm{M}^{+}\right), 187(\mathrm{BP})$ \\
\hline q & dodecanoic acid butylester & $256\left(\mathrm{M}^{+}\right), 201,183,57,56(\mathrm{BP})$ \\
\hline r & hexadecanone & $204\left(\mathrm{M}^{+}\right), 58(\mathrm{BP})$ \\
\hline s & phytane & \\
\hline $\mathrm{t}$ & pentadecanoic acid methylester & $256\left(\mathrm{M}^{+}\right), 87,74(\mathrm{BP})$ \\
\hline $\mathrm{u}$ & ketone? & 58,43 (BP) \\
\hline $\mathbf{v}$ & phthalate & 149 (BP) \\
\hline w & heptadecanone & $254\left(\mathrm{M}^{+}\right), 58(\mathrm{BP})$ \\
\hline $\mathrm{x}$ & hexadecanoic acid methylester & $270\left(\mathrm{M}^{+}\right), 87,74(\mathrm{BP})$ \\
\hline y & benzoate? & $228\left(\mathrm{M}^{+}\right), 105(\mathrm{BP}), 77$ \\
\hline z & branched $\mathrm{C}_{16}$ alcohol TMS ether & $314\left(\mathrm{M}^{+}\right), 299,117,75,73(\mathrm{BP})$ \\
\hline A & tetradecanoic acid butylester & $284\left(\mathrm{M}^{+}\right), 229,211,57,56(\mathrm{BP})$ \\
\hline B & hexadecanol TMS ether & $314\left(\mathrm{M}^{+}\right), 299,75$ \\
\hline C & dibutylphthalate & $223,205,149$ (BP) \\
\hline D & octadecanone & $286\left(\mathrm{M}^{+}\right), 58(\mathrm{BP})$ \\
\hline $\mathbf{E}$ & benzoate? & $286\left(\mathrm{M}^{+}\right), 271,105(\mathrm{BP}), 77$ \\
\hline $\mathbf{F}$ & heptadecanoic acid methylester & $284\left(\mathrm{M}^{+}\right), 87,74(\mathrm{BP})$ \\
\hline G & heptadecanol TMS ether & $328\left(\mathrm{M}^{+}\right), 75(\mathrm{BP})$ \\
\hline $\mathrm{H}$ & nonanedioic acid dibutylester & $227,171,152,55$ (BP) \\
\hline I & unknown & $270\left(\mathrm{M}^{+}\right), 255,173,159$ \\
\hline $\mathrm{J}$ & nonadecanone & $282\left(\mathrm{M}^{+}\right), 58(\mathrm{BP})$ \\
\hline $\mathrm{K}$ & octadecanoic acid methylester & $298\left(\mathrm{M}^{+}\right), 87,74(\mathrm{BP})$ \\
\hline $\mathrm{L}$ & branched $\mathrm{C}_{18}$ alcohol TMS ether? & $342\left(\mathrm{M}^{+}\right), 327,249,117,73$ (BP), 57 \\
\hline M & octadecanol TMS ether & $342\left(\mathrm{M}^{+}\right), 327,75(\mathrm{BP})$ \\
\hline $\mathrm{N}$ & simonellite & $252\left(\mathrm{M}^{+}\right), 237(\mathrm{BP}), 195,178,165$ \\
\hline O & alkylbenzene? & $308\left(\mathrm{M}^{+}\right), 137,119,105$ \\
\hline $\mathbf{P}$ & hexadecanoic acid butylester? & $312\left(\mathrm{M}^{+}\right), 56(\mathrm{BP})$ \\
\hline Q & eicosanone & $296\left(\mathrm{M}^{+}\right), 58(\mathrm{BP})$ \\
\hline $\mathbf{R}$ & nonadecanoic acid methylester & $312\left(\mathrm{M}^{+}\right), 87,74(\mathrm{BP})$ \\
\hline$S$ & retene & $234\left(\mathrm{M}^{+}\right), 219$ (BP), 204, 189, 108 \\
\hline $\mathrm{T}$ & unknown & $255,199,175,139$ \\
\hline $\mathrm{U}$ & unknown & 224,111 \\
\hline V & unknown & $358\left(\mathrm{M}^{+}\right), 343,261,247,73(\mathrm{BP})$ \\
\hline W & nonadecanol TMS ether & $356\left(\mathrm{M}^{+}\right), 341,75(\mathrm{BP})$ \\
\hline $\mathrm{X}$ & heneisosanone & $310\left(\mathrm{M}^{+}\right), 58(\mathrm{BP})$ \\
\hline $\mathrm{Y}$ & eicosanoic acid methylester & $326\left(\mathrm{M}^{+}\right), 87,74(\mathrm{BP})$ \\
\hline $\mathrm{Z}$ & eisocanol TMS ether & $370\left(\mathrm{M}^{+}\right), 355,75(\mathrm{BP})$ \\
\hline$a^{\prime}$ & hexanedioic acid dioctylester & $369,147,129$ (BP), 112 \\
\hline$b^{\prime}$ & unknown & 171 (BP), $127,114,99,75$ \\
\hline $\mathrm{c}^{\prime}$ & tricosanone & $338\left(\mathrm{M}^{+}\right), 59(\mathrm{BP})$ \\
\hline$d^{\prime}$ & docosanoic acid methylester & $354\left(\mathrm{M}^{+}\right), 87,74(\mathrm{BP})$ \\
\hline $\mathbf{e}^{\prime}$ & docosanol TMS ether & $398\left(\mathrm{M}^{+}\right), 393,75(\mathrm{BP})$ \\
\hline $\mathrm{f}^{\prime}$ & dioctylphthalate & $279,165,149$ (BP) \\
\hline $\mathrm{g}^{\prime}$ & unknown & $372\left(\mathrm{M}^{+}\right), 357,73(\mathrm{BP})$ \\
\hline$h^{\prime}$ & tetracosanone & $352\left(\mathrm{M}^{+}\right), 59(\mathrm{BP})$ \\
\hline $\mathrm{i}^{\prime}$ & tricosanoic acid methylester & $368\left(\mathrm{M}^{+}\right), 87,74(\mathrm{BP})$ \\
\hline $\mathrm{j}^{\prime}$ & benzofluoranthene & $252\left(\mathrm{M}^{+}, \mathrm{BP}\right)$ \\
\hline $\mathrm{k}^{\prime}$ & pentacosanone & $366\left(\mathrm{M}^{+}\right), 59(\mathrm{BP})$ \\
\hline $\mathrm{l}^{\prime}$ & tetracosanoic acid methyl ester & $382\left(\mathrm{M}^{+}\right), 87,74(\mathrm{BP})$ \\
\hline $\mathrm{m}^{\prime}$ & tetracosanol TMS ether & $426\left(\mathrm{M}^{+}\right), 411,75(\mathrm{BP})$ \\
\hline $\mathbf{n}^{\prime}$ & unknown & $72,59(\mathrm{BP})$ \\
\hline$o^{\prime}$ & hexacosanone & $380\left(\mathrm{M}^{+}\right), 59(\mathrm{BP})$ \\
\hline $\mathbf{p}^{\prime}$ & pentacosanoic acid methylester & $396\left(\mathrm{M}^{+}\right), 87,74(\mathrm{BP})$ \\
\hline $\mathbf{q}^{\prime}$ & unknown & $414\left(\mathrm{M}^{+}\right), 383,155(\mathrm{BP})$ \\
\hline $\mathbf{r}^{\prime}$ & heptacosanone & $394\left(\mathrm{M}^{+}\right), 59(\mathrm{BP})$ \\
\hline $\mathbf{s}^{\prime}$ & hexacosanoic acid methylester & $410\left(\mathrm{M}^{+}\right), 87,74(\mathrm{BP})$ \\
\hline $\mathrm{t}^{\prime}$ & unknown & $398\left(\mathrm{M}^{+} ?\right), 383,217,191,190172,163$ \\
\hline $\mathbf{u}^{\prime}$ & unknown & 263,223 (BP), 73 \\
\hline$v^{\prime}$ & 30-nor-neohop-13(18)-ene & $396\left(\mathrm{M}^{+}\right), 204,191$ \\
\hline$w^{\prime}$ & octacosanoic acid methylester & $438\left(\mathrm{M}^{+}\right), 87,74(\mathrm{BP})$ \\
\hline $\mathrm{x}^{\prime}$ & hop-17(21)-ene & $410\left(\mathrm{M}^{+}\right), 367,231,191$ \\
\hline$y^{\prime}$ & octacosanol TMS ether & $482\left(\mathrm{M}^{+}\right), 411,75(\mathrm{BP})$ \\
\hline $\mathrm{z}^{\prime}$ & unknown & 277,237 (BP), 73 \\
\hline
\end{tabular}


Table 4. Compounds detected in the extractable bitumens of sediments from Legs 122 and 123.

\begin{tabular}{|c|c|c|}
\hline Code & Compound & Mass spectral data $(\mathrm{m} / \mathrm{z})$ \\
\hline $\mathrm{A}^{\prime}$ & cholest- 5 -en-3 $\beta$-ol TMS ether & $458\left(\mathrm{M}^{+}\right), 368,353,129(\mathrm{BP})$ \\
\hline $\mathrm{B}^{\prime}$ & neohop-13(18)-ene & $410\left(\mathrm{M}^{+}\right), 218,205,191(\mathrm{BP})$ \\
\hline $\mathrm{C}^{\prime}$ & 30 -nor-17 $\beta(\mathrm{H})$-hopane & $398\left(\mathrm{M}^{+}\right), 383,369,191,177$ (BP) \\
\hline $\mathrm{D}^{\prime}$ & triacontanoic acid methylester & $466\left(\mathrm{M}^{+}\right), 87,74(\mathrm{BP})$ \\
\hline $\mathrm{E}^{\prime}$ & $17 \beta(\mathrm{H})$-hopane & $412\left(\mathrm{M}^{+}\right) 397,369,191$ (BP) \\
\hline $\mathrm{F}^{\prime}$ & 24-ethylcholest-5-en- $3 \beta$-ol TMS ether & $486\left(\mathrm{M}^{+}\right), 396,381,129(\mathrm{BP})$ \\
\hline $\mathrm{G}^{\prime}$ & 24 -ethylcholestan- $3 \beta$-ol TMS ether & $488\left(\mathrm{M}^{+}\right), 473,398,393,215,75$ (BP) \\
\hline $\mathrm{H}^{\prime}$ & $\mathrm{C}_{30}$ triterpane & $412\left(\mathrm{M}^{+}\right), 397,191$ (BP) \\
\hline $\mathbf{I}^{\prime}$ & $17 \beta(\mathrm{H})$-homohopane & $426\left(\mathrm{M}^{+}\right), 205(\mathrm{BP}), 191$ \\
\hline $\mathbf{J}^{\prime}$ & dotriacontanoic acid & $494\left(\mathrm{M}^{+}\right), 87,74(\mathrm{BP})$ \\
\hline
\end{tabular}

Note: $\mathrm{M}^{+}=$molecular ion; $\mathrm{BP}=$ base peak.

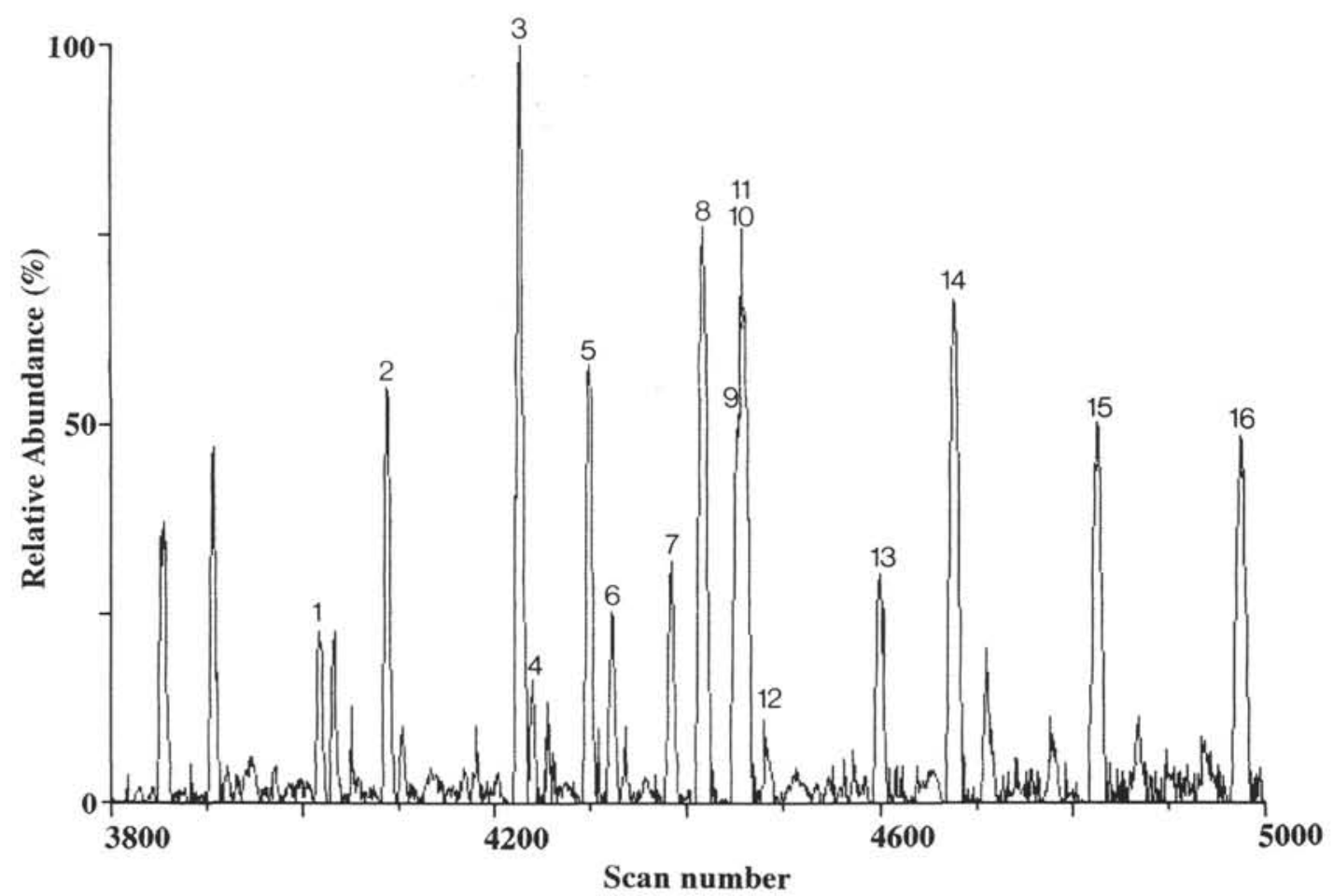

Figure 6. M/z 191 mass fragmentogram indicating hopanoid hydrocarbon distribution in Sample 122-760B-8R-CC, 16-21 cm, typical of Triassic sediments on the Wombat Plateau. Compounds identified: $1=22,29,30$-trisnor$17 \alpha(\mathrm{H})$-hopane; 2 = 22,29,30-trisnor-17 $\beta(\mathrm{H})$-hopane; 3 = 30-norneohop-13(18)-ene; 4 = 30-norhop-17(21)-ene; $5=$ hop-17(21)-ene; $6=30$-normoretane; $7=17 \alpha(\mathrm{H})$-hopane; $8=$ neohop-13(18)-ene; $9=$ moretane; $10=$ neohop$13(18)$-ene; $11=$ homohop-17(21)-ene(22S); $12=$ homohop-17(21)-ene(22R); $13=17 \alpha(\mathrm{H})$-homohopane; $14=$ $17 \beta(\mathrm{H})$-hopane; $15=$ unknown $\mathrm{C}_{30}$ triterpane $\left(\mathrm{M}^{+}=412,397,369,191\right)$; and $16=17 \beta(\mathrm{H})$-homohopane. 

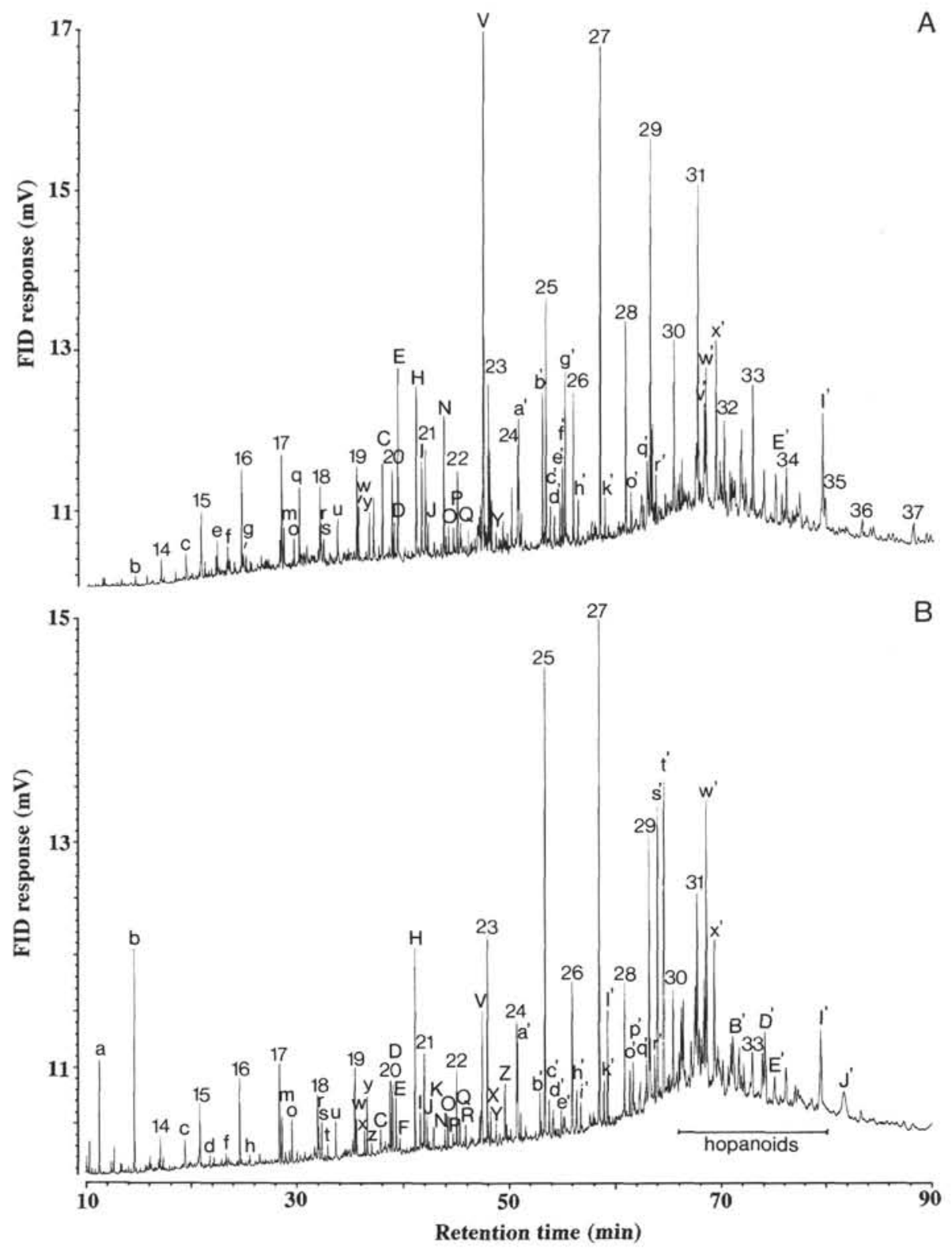

Figure 7. Capillary column gas chromatograms of the total extracts of two selected Lower Cretaceous sediments from the Exmouth Plateau. Numbers indicate $n$-alkanes. For further compound identifications see Table 4. A. Sample 122-762C-81X-3, 74-81 cm (852.24 mbsf; $1.49 \%$ $\mathrm{C}_{\text {org }}$; lower Valanginian). B. Sample 122-763C-8R-3, 16-23 cm (673.76 mbsf; $1.87 \% \mathrm{C}_{\text {org }}$; upper Berriasian). 

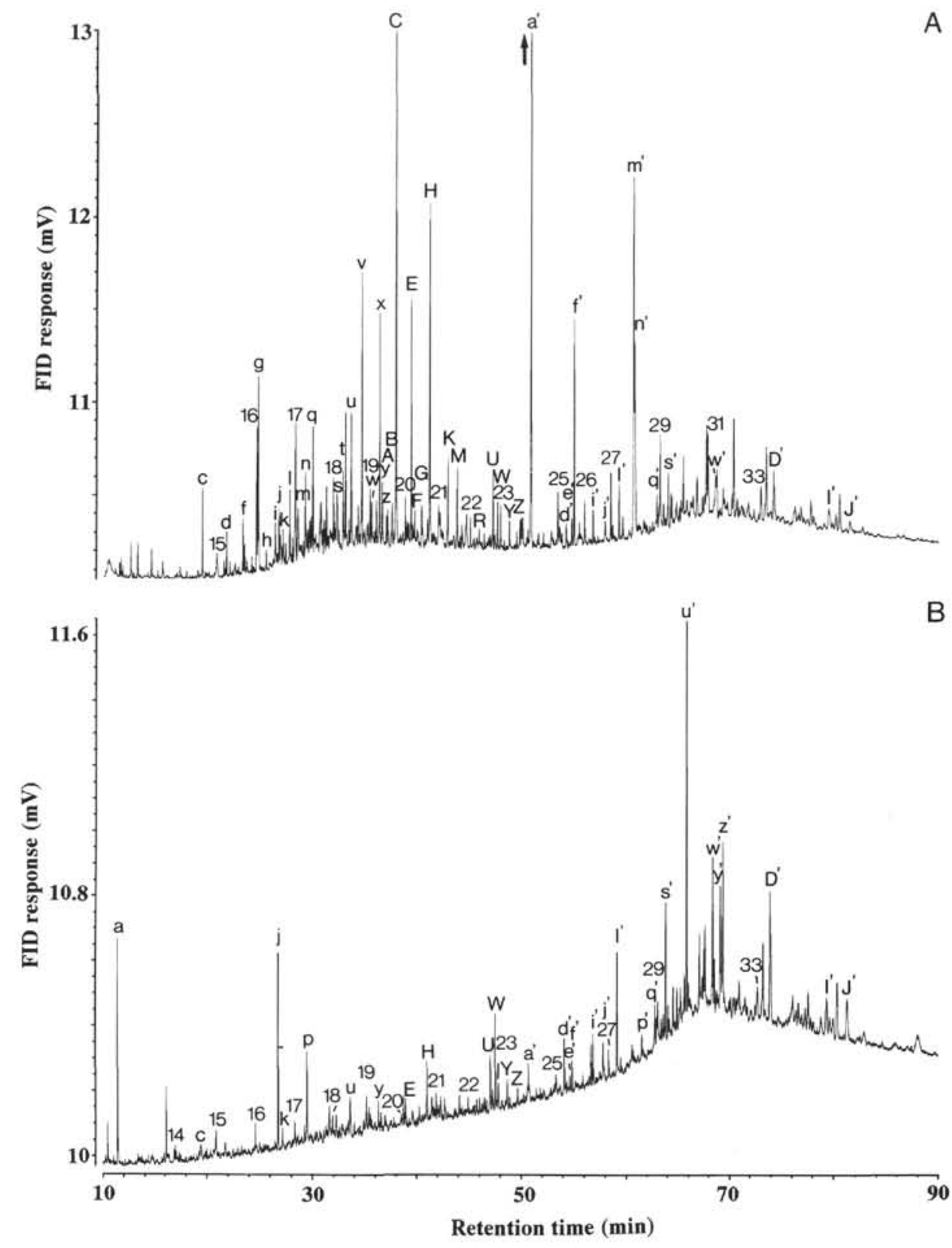

Figure 8. Capillary column gas chromatograms of the total extracts of two Cenomanian/Turonian black shales from Site 763 on the Exmouth Plateau. Numbers indicate $n$-alkanes. For further compound identification see Table 4. A. Sample $122-763 \mathrm{C}-2 \mathrm{R}-1,19-21 \mathrm{~cm}$ (385.20 mbsf; $2.45 \%$ $\left.\mathrm{C}_{\text {org }}\right)$. B. Sample 122-763C-2R-1, 28-30 cm (385.28 mbsf; $\left.25.9 \% \mathrm{C}_{\text {org }}\right)$. 


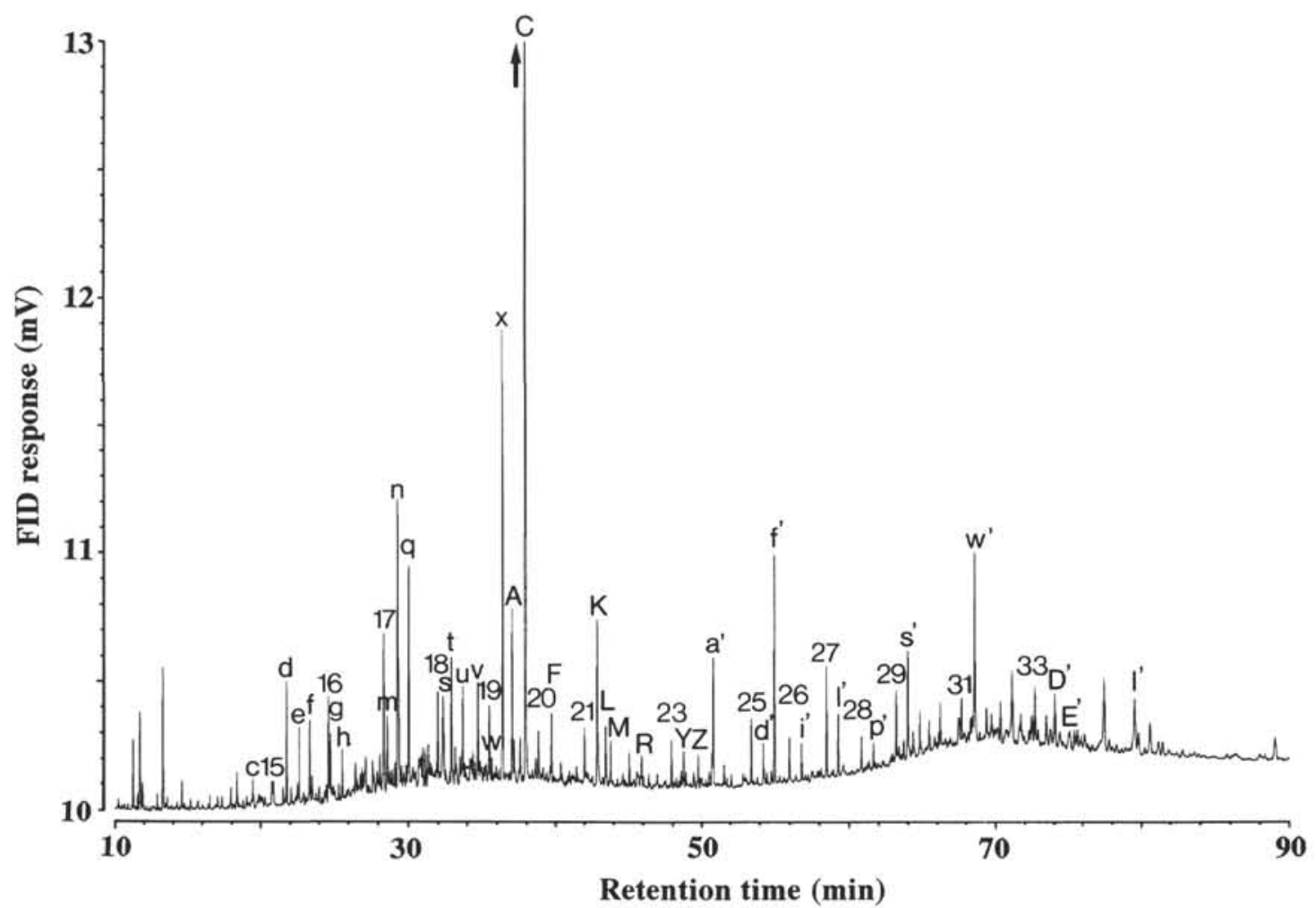

Figure 9. Capillary column gas chromatogram of the total extract of the lower Aptian Sample 123-765C-45R-4, 100-104 $\mathrm{cm}$ (773.72 mbsf; $4.35 \% \mathrm{C}_{\text {org }}$ ) from Site 765 in the Argo Abyssal Plain. Numbers indicate $n$-alkanes. For further compound identification see Table 4. 